

\section{Argonne National Laboratory}

Argonne National Laboratory, with facilities in the states of Illinois and Idaho, is owned by the United States government, and operated by the University of Chicago under the provisions of a contract with the Department of Energy.

This technical memo is a product of Argonne's Energy Systems (ES)

Division. For information on the division's scientific and engineering activities, contact:

Director, Energy Systems Division

Argonne National Laboratory

Argonne, Illinois 60439-4815

Telephone (708) 252.3724

Presented in this technical memo are preliminary results of ongoing work or work that is more limited in scope and depth than that described in formal reports issued by the ES Division.

\section{Disclaimer}

This report was prepared as an account of work sponsored by an agency of the United States Govemment. Neither the United States Govemment nor any agency thereof, nor any of their employees, makes any warranty, express or implied, or assumes any legal liability or responsibility for the accuracy, completeness, or usefulness of any information, apparatus, product, or process disclosed, or represents that its use would not infringe privately owned rights. Reference herein to any specific commercial product, process, or service by trade name, trademark, manufacturer, or otherwise, does not necessarily constitute or imply its endorsement, recommendation, or favoring by the United States Govemment or any agency thereof. The views and opinions of authors expressed herein do not necessarily state or reflect those of the United States Government or any agency thereof.

Reproduced directly from the best avaiiable cupy.

Available to DOE and DOE contractors from the Office of Scientific and Technical Information, P.O. Box 62, Oak Ridge, TN 37831; prices available from (615) $576-8401$, FTS 626-8401.

Available to the public from the National Technical Information Service, U.S. Department of Commerce, 5285 Port Royal Road, Springfield, VA 22161. 


\section{Minimal Technologies Application Project: Planning and Installation}

by S.D. Zellmer, R.R. Hinchman, W.D. Severinghaus, ${ }^{\star}$ D.O. Johnson, and J.J. Brent*

Reclamation Engineering and Geosciences Section, Energy Systems Division, Argonne National Laboratory, 9700 South Cass Avenue, Argonne, Illinois 60439

March 1989

Work supported under a military interdepartmental purchase request from the U.S. Department of Defense U.S. Army Corps of Engineers Construction Engineering Research Laboratory, through U 3. Department of Energy contract W-31-109-Eng-38

"Severinghaus is affiliated with the U.S. Army Corps of Engineers, Construction Engineering Research Laboratory, Environmental Division, Champaign, Illinois; and Brent with the Environmental Management Office, Directorate of Engineering and Housing, Headquarters, 282nd Base Support Battalion, Hohenfels, U.S. Army. 


\section{Contents}

Acknowledgments...........................................................

Abstract............................................................................ 1

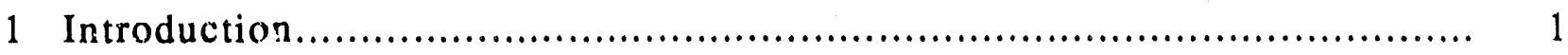

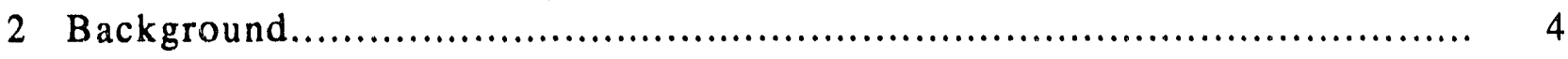

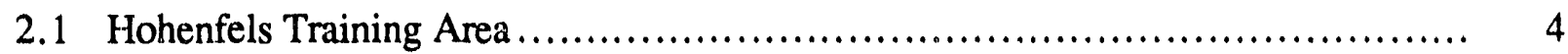

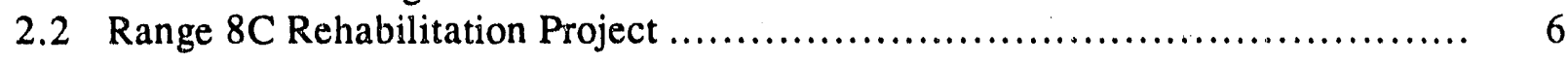

3 Goal, Objectives, and Approach ............................................. 7

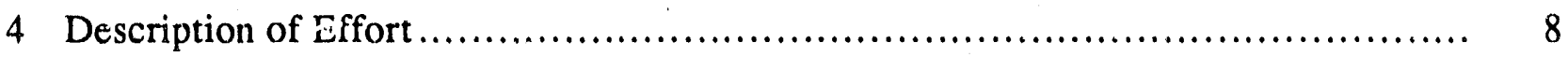

4.1 Work Plan Development ............................................... 8

4.1.1 Seedbed Preparation ................................................... 8

4.1 .2 Closure Periods ....................................................... 9

4.1.3 Site Plan Development ................................................. 10

4.1 .4 Recommendation s................................................... 12

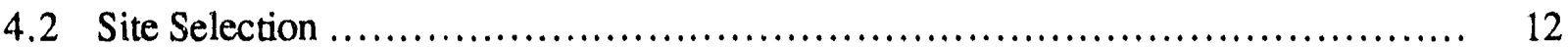

4.2.1 Site Selection Criteria ................................................ 12

4.2.2 Site Location and Description ..................................... 13

4.3 Specification Development................................................. 14

4.3.1 Soil Amendments ................................................... 14

4.3.2 Seed Mixture ........................................................ 15

4.3.3 Preparation of Specifications ...................................... 17

4.4 Site Establishment........................................................ 17

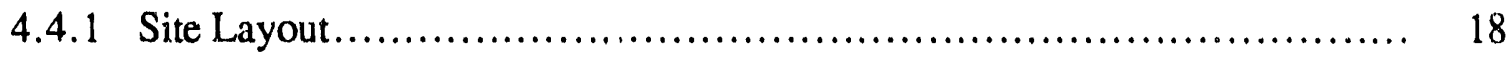

4.4 .2 Fence Construction .................................................... 19

4.4.3 Soil Sample Collection ............................................... 20

4.4.4 Transect Establishment ................................................. 21

4.4.5 Contractor Activities ................................................ 22

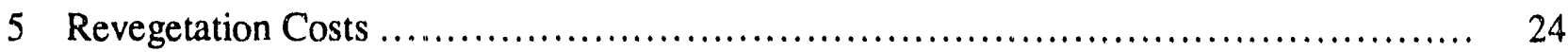

6 Observations and Recommendations ....................................... 26

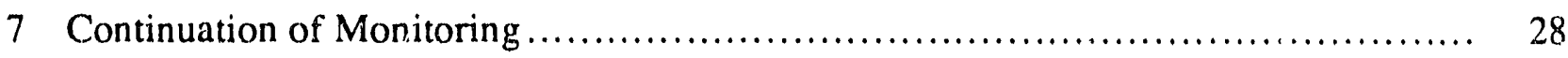

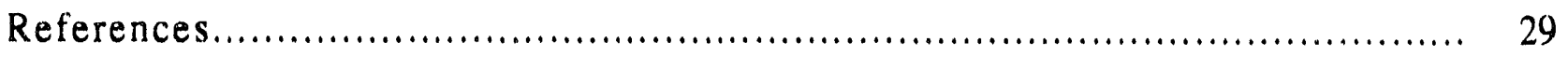




\section{Contents (Cont'd)}

Appendix A: Specifications for Minimal Technologies Application

Rehabilitation Project

Appendix B: Bid Package for Minimal Technologies Application

Rehabilitation Project

\section{Figures}

1 Location of Hohenfels Training Area in the Federal Republic of Germany................... 3

2 Location of Minimal Technologies Application Project at Hohenfels Training Area......... 5

3 Schematic of Matrix Site Design ............................................... 11

4 Planned Design for the Relocated Study Site ..................................... 19

5 View of Study Site during Fence Construction, Mid-June 1987............................ 20

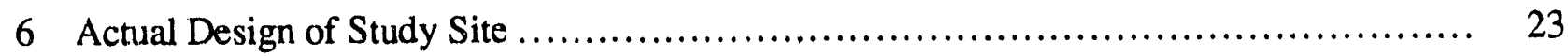

\section{Tables}

1 Analytical Results and Means of Surface Soils from the Range 8C Project Site .......... 15

2 Seed Mixture and Seeding Rate Used at the MTA Site.............................. 16

3 Analytical Results and Means of Surface Soils from the Study Site................... 21

4 Bid Prices and Actual Contract Costs for Seedbed Preparation and

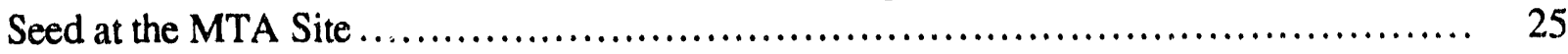

5 Estimated Representative Revegetation Costs for Hohenfels Training Area.............. 25 


\section{Acknowledgments}

The planning and installation of the Minimal Technologies Application Project at the Hohenfels Training Area (HTA) in West Germany was made possible through the contributions and cooperation of a number of individuals and organizations. Colonel John E. Counts, the HTA Commander, supported the study and provided the site; special thanks and recognition are extended to him and his staff.

Captain Eric E. Paulson and his staff at the Hohenfels Directorate of Engineering and Housing (DEH) provided support in various ways on numerous occasions. Their assistance ranged from obtaining gate passes for Argonne staff to conducting tours of HTA to locate a suitable study site. Horst Manhart of DEH provided the labor force and material and coordinated installation of the concertina wire. We are indebted to Capt. Paulson and his staff for their assistance.

The U.S. Army Corps of Engineers Construction Engineering Research Laboratory (USACERL) is gratefully acknowledged for providing funding for Argonne's effort. Winifred Hodge of USACERL made a large and valuable contribution; her help and assistance in working with the German rehabilitation contractor is especially appreciated.

Sue Wilkey rendered a valuable service by translating the Specifications and the Bid Package from English into German. Her understanding and assistance with this task made our work easier.

Finally, special thanks and appreciation is extended to Barbara Sullivan for her assistance throughout the study, particularly in the preparation of the project specifications in both English and German and in the production of this document. 


\title{
Minimal Technologies Application Project: Planning and Installation
}

\author{
by \\ S.D. Zellmer, R.R. Hinchman, W.D. Severinghaus, D.O. Johnson, and J.J. Brent
}

\begin{abstract}
Intensive and continuous tactical training during the last 35 years at the Hohenfels Training Area in West Germany has caused the loss of vegetative ground cover and has accelerated soil erosion rates, resulting in extensive environmental daniage, safety hazards, and unrealistic training habitats. The objectives of this project are to develop and evaluate revegetation procedures for establishing adequate vegetative cover to control erosion at minimal costs and disruption to training activities. This project involved the development and installation of 12 revegetation procedures that combined four seedbed preparation methods and seeding options with three site-closure periods. In March 1987, the four seedbed preparation/seeding options and closure periods were selected, a study site design and location chosen, and specifications for the revegetation procedures developed. A German rehabilitation contractor attempted the specified seedbed preparation and seeding on the 13.5-ha site in June, but abnormally high rainfall, unusually wet site conditions, and lack of adequate equipment prevented the contractor from completing six of the 12 planned procedures. Planning and execution of the project has nonetheless provided valuable information on the importance and use of soil analytical results, seed availability and cost data, contractor equipment requirements, and time required for planning future revegetation efforts. Continued monitoring of vegetative ground cover at the site for the next two years, combined with cost information, will provide necessary data to determine which of the six revegetation procedures is the most effective. These data will be used in planning future rehabilitation efforts on tactical training areas.
\end{abstract}

\section{Introduction}

Approximately one-third of the U.S. Army is deployed in western Europe, but the total land area available for U.S. military personnel in Europe is only about 87,900 ha $(217,200$ acres). This is an area approximately equal in size to Fort Hood, Texas, but less than $2 \%$ of the total land area is available for housing and training. Most combat units assigned to U.S. Army Europe (USAREUR) are stationed in the Federal Republic of Germany (FRG); because of the strategic location of Germany, these units must maintain combat readiness by constant tactical training. 
Tactical training in the densely populated and highly industrialized FRG is expensive because of the high costs of compensation for maneuver damage. The rimber and size of existing tactical training areas is limited because of intensive land use for farming, forestry, and recreation, resulting in intensive and continuous use of existing installations. Larger U.S. tactical training areas are also often used by combat units of other North Atlantic Treaty Organization forces. In addition, new and improved weapon systems have changed training doctrines, requiring combat units to operate over large areas and engage targets at greater ranges than formerly. The result is very high training pressure (i.e., military use of a training area during a given time period) on U.S. training areas in West Germany. This intensive and continued use of U.S. training areas in West Germany has damaged or destroyed vegetative ground cover, causing accelerated soil erosion. This environmental damage produces safety hazards and unrealistic training conditions and can degrade the environmental quality on adjacent lands.

Vegetative ground cover is critical for environmentally sound, safe, and realistic training areas. Plants intercept raindrops, reducing their impact energy and potential for erosion. Plant roots bind soil particles, preventing sheet erosion and increasing soil porosity that results in reduced runoff volume. Runoff velocity is lowered by vegetative ground cover; this prevents the concentration of overland flow and potential rill development. Rills become gullies that increase in size with each storm, and gullies in training areas are hazards to vehicles and personnel. Sheet, rill, and gully erosion produce sediments that are carried into receiving streams and onto adjacent lands. Runoff and sediments are often transported off the training area, degrading adjacent environments and causing concern to local residents and officials. In addition, a barren and eroded landscape is an unrealistic training habitat. The most cost-effective prevention against soil erosion is a dense, self-sustaining plant cover. Hence, establishment and maintenance of vegetative ground cover is essential for improving environmental quality, training realism, and safety at training areas.

The Minimal Technologies Application (MTA) project was initiated in 1987 at Hohenfels Training Area (HTA) in West Germany (Fig. 1). Goals were to develop and evaluate revegetation procedures for establishing vegetative ground cover on tactical training areas for minimal costs and closure periods. MTA is the second of several rehabilitation demonstration projects being conducted by Argonne National Laboratory (ANL) in West Germany under the sponsorship of the U.S. Army Corps of Engineers Coristruction Engineering Research Laboratory (USACERL). Each of these revegetation research projects is aimed at developing reclamation and maintenance technologies necessary to rehabilitate tactical training areas. The projects are part of the Integrated Training Area Management (ITAM) program being developed by USACERL at HTA for the Seventh Army Training Command of USAREUR.

The MTA project was designed to evaluate 12 revegetation procedures consisting of four seedbed preparation methods and seeding options combined with three closure tested procedures. This report describes in detail the planning and initiation of the MTA revegetation demonstration project at HTA. Vegetative ground cover is to be measured three times each growing season for two or more years to determine the effectiveness of each revegetation procedure. Study results will provide basic information on seedbed preparation methods and seeding options in combination with the time required to establish revegetation for effective erosion control at HTA. Information from this study can be applied to training area rehabilitation efforts at other installations in West Germany and the United States having similar soil and climatic conditions. 


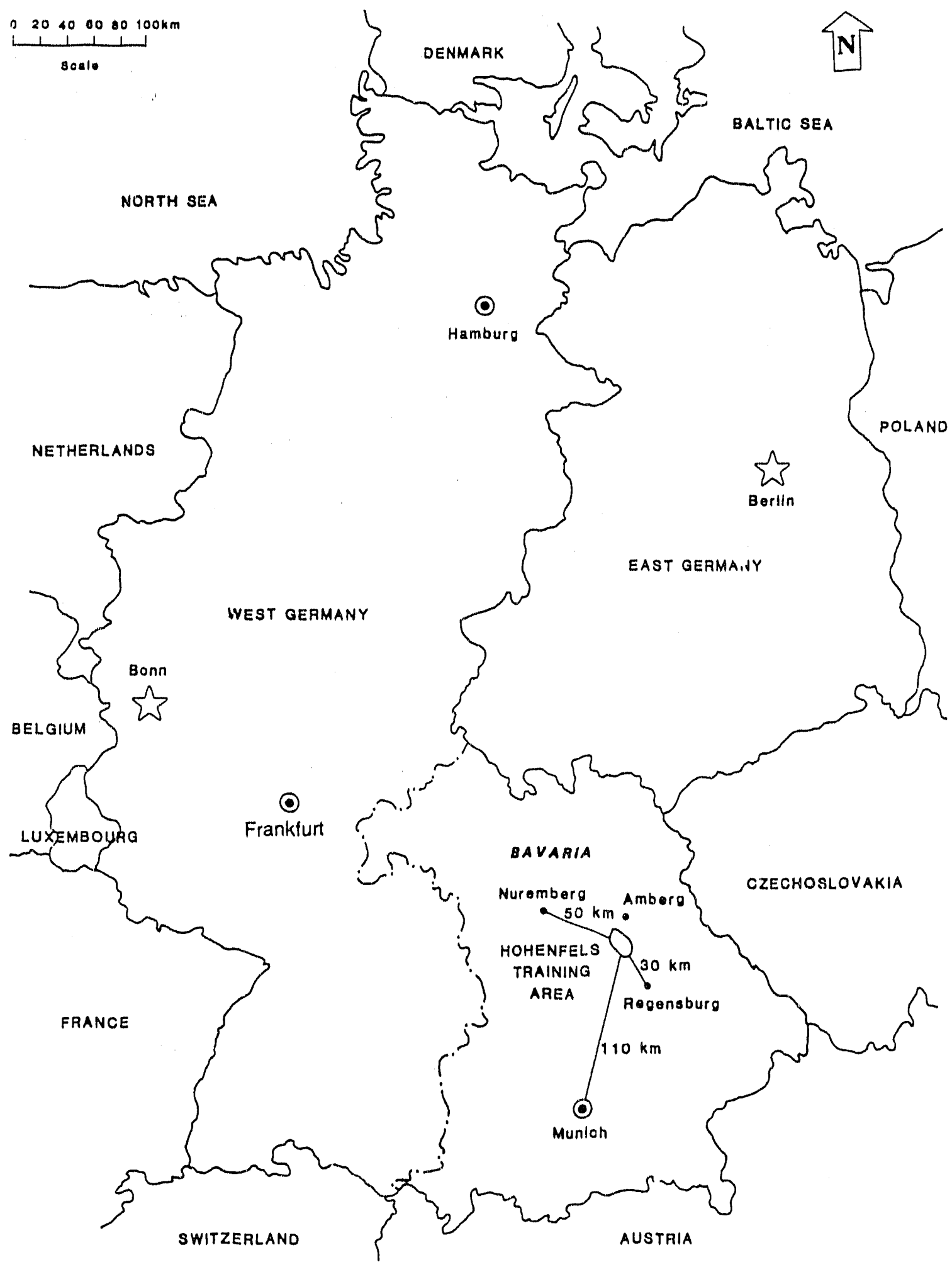

FIGURE 1 Location of Hohenfels Training Area in the Federal Republic of Germany 


\section{Background}

The Environmental Division of USACERL, located in Champaign, Illinois, is responsible for developing the ITAM program for the U.S. Army. The goal of this program is to provide the process and tools to support management programs that enhance resource conservation and training needs at U.S. Army installations. Major thrusts of the ITAM program are to (1) assess environmental conditions and classify training area use capacity, (2) integrate environmental concerns with long-term training needs, (3) develop a troop elı vironmental awareness educational program, (4) produce a computer-based management and scheduling system to aid in management decisions, and (5) develop reclamation procedures for rehabilitating and maintaining training areas.

Development of the ITAM program for HTA was initiated by USACERL in 1985. One major thrust of the program was to develop and demonstrate integrated rehabilitation and maintenance procedures for reducing soil erosion and other environmental damage and to produce a more realistic and safer training habitat. USACERL requested the assistance of the Reclamation Engineering and Geosciences Section of the Energy Systems Division at ANL in the development and demonstration of these rehabilitation and maintenance procedures. Argonne was selected because of its $10+$ years of experience in applied and basic research in land reclamation and because of a similar USACERL-ANL training range rehabilitation demonstration project under way at Fort Carson, Colorado.

\subsection{Hohenfels Training Area}

The HTA is located amid the forest and farmland of the Oberpfalz region in the independent state of Bavaria, Federal Republic of Germany. HTA was established as a military training area by the German Armed Forces (Wehrmacht) in 1938 and was used to train German forces and house prisoners of war during World War II. The American Army occupied HTA in April 1945, and parts of the base were used as a displaced-persons camp until 1949. The U.S. Army requisitioned HTA as a training area in 1951 and enlarged it to its current area of 16,200 ha (40,000 acres) the next year. HTA is part of the Seventh Army Training Command and is the largest maneuver area available to U.S. troops in Europe.

The Oberpfalz region has a humid mesothermal climate with average annual precipitation of about $960 \mathrm{~mm}$ (38 in.). Precipitation is mostly rainfall and is evenly distributed throughout the year. Snowfall can occur from late October through early April, but snow cover usually lasts only a few days because of above-freezing daytime temperatures. Winters are moderately cold, with daytime temperatures averaging about $0^{\circ} \mathrm{C}\left(32^{\circ} \mathrm{F}\right)$ in January. Summers are cool with warm days, cool nights, and average temperatures of $13^{\circ} \mathrm{C}\left(55^{\circ} \mathrm{F}\right)$ during July, the warmest month. This climate provides a long growing season from about mid-April through late October, and grasses may remain green throughout a mild winter.

The elevation of HTA is slightly higher than that of the surrounding countryside, and the landscape is rolling with alternating ridges and valleys. Slopes range from less than $10 \%$ on the 
valley floors to $45 \%$ or more near the ridge tops, with most valley-side slopes ranging from $10 \%$ to $30 \%$. HTA is in a groundwater recharge zone, and vegetated undisturbed soils have a moderate to high infiltration rate; most of the streams in the valleys are intermittent. HTA contains the headwaters of only two perennial streams, the Kesselgraben and the Froellenbach, and major surface drainage flows into three rivers adjacent to the training area. General boundaries of HTA are the Lauterach River on the north, the Viles River on the east, and Forellenbach River on the southeast (Fig. 2).

Surrounding countryside is divided almost equally between forest and farmland. Most of the ridge tops and steeply sloped areas are in intensely managed coniferous forest, but some mixed stands are present. Valley floors and moderately sloping hillsides are used to grow small grains, corn for silage, and forage crops. Evidence of this previously mixed forest/agricultural land use is seen in the current vegetation patterns at HTA. Ridge tops and steeper sloped areas are primarily occupied by conifer forest managed by the German Federal Forest Service. There is evidence of old field boundaries in the form of ridges made of rocks collected from the old farm field on many of the hillsides. Fields once used for forage crops probably became upland meadows, and cultivated fields presumably reverted to abandoned-field communities when the training area was established.

The vegetative communities that developed during military use of the meadows and old fields have plant species adapted to the soils and climate of the region, but many colonizing species

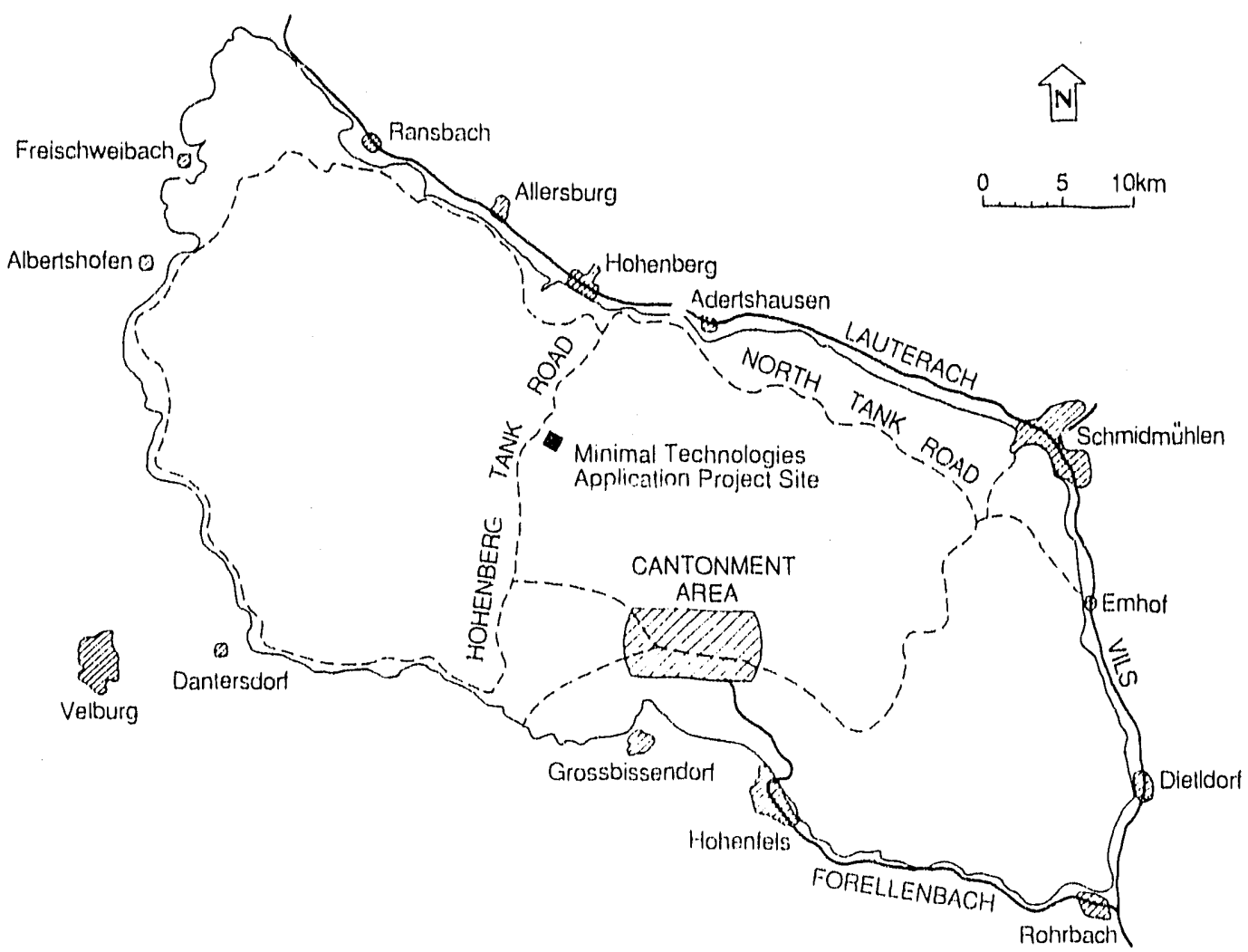

FIGURE 2 Location of Minimal Technologies Application Project at Hohenfels Training Area 
are less than ideal for effective erosion control and training realism. The continued and intensive use of H'TA for military tactical training has damaged or destroyed much of the vegetative ground cover in nonforest areas. This has resulted in accelerated soil erosion, runoff, and environmental damage on HTA; it may also adversely influence the water quality in adjacent rivers.

\subsection{Range 8C Rehabilitation Project}

ANL participation in the ITAM program began with the planning for the Range $8 \mathrm{C}$ Rehabilitation Demonstration Project at HTA in late 1985. This project was designed to demonstrate that training areas could be rehabilitated to improve the environmental quality, training realism, and safety at HTA by reestablishing vegetative ground cover and controlling erosion. The ANL field effort began in the spring of 1986 with the selection of Range 8C at HTA as an initial rehabilitation demonstration site because it had training damage and other conditions typical of HTA. An inventory of conditions at the demonstration site was made during the early summer; information was collected on (1) type and amount of vegetation, erosion, and training damage; (2) topography; and (3) soil characteristics. This site-specific information was combined with various reclamation options to develop individual rehabilitation prescriptions for subareas of Range 8C. Individual prescriptions included (1) fertilization, (2) several seedbed preparation methods and two seed mixtures, (3) a graded terrace and grassed waterway system, and (4) three types of porous water control structures. Prescriptions were installed by a German contractor in September 1986, and the site was closed for one year to allow vegetation to become established. A detailed description of the development and installation of prescriptions at Range $8 \mathrm{C}$ is available from USACERL (Zellmer et al. 1987).

Monitoring to determine the effectiveness of individual prescriptions at Range $8 \mathrm{C}$ began during installation of the prescriptions. Plant cover on each prescription area is measured by the point-intercept method (Chambers and Brown 1983) three times each growing season. The effectiveness of structures (e.g., waterways, terraces, water control structures) is being determined by field observations. Preliminary results indicate good success in establishing acceptable plant cover after all revegetation prescriptions were installed. However, the costs of some seedbed preparation operations (leveling, ripping, and tilling) and seed planting methods (drilling and hydroseeding) are high, indicating that some of the revegetation prescriptions may not be costeffective for all areas at HTA. Other field observations indicate it would not be practical to close a training range for extended periods as part of the revegetation process. These preliminary observations indicated the need for development and evaluation of revegetation procedures that are less expensive and that require shorter closing periods than those used at Range 8C. The result was the MTA Project. 


\section{Goal, Objectives, and Approach}

The goal of the Minimal Technologies Application project is to develop and evaluate revegetation procedures (seedbed preparation methods and seeding options combined with various periods of site closure) that will permit establishment of adequate vegetative ground cover to control erosion at minimal cost with minimal disruption (i.e., site closure) to military training. To attain this goal, four specific project objectives were developed:

- Determine if seedbed preparation methods and seeding options influence vegetation establishment.

- Determine if lengih of closure period affects vegetation establishment.

- Evaluate selected revegetation procedures under field conditions.

- Develop recommendations for future training area revegetation.

The MTA project has two phases. Tasks in the first (planning and initiation) included (1) development of a project work plan, (2) selection of a study site, (3) development of specifications for the rehabilitation contractor, and (4) establishment of the tudy site. This phase began with work-plan development and preliminary study-site selection in March 1987 and was completed with the instailation of the revegetation procedures in late June of that year. This report provided a detailed description of four tasks included in the first phase of the project and observations made during installation of the revegetation procedures.

The second phase (monitoring) consists of a single task: measurement of vegetative ground cover on established transects in each of the test areas. Plant cover measurements are to be made with the point-intercept method (Chambers and Brown 1983) during the spring, summer, and fall for two or more growing seasons. This frequency and duration of data collection is necessary to evaluate all treatments for one year or more after reopening of all areas to military use. Vegetation data and field observations will be used to assess the effectiveness of the revegetation procedures. Detailed results of the monitoring phase of the MTA project will be provided in a second report. 


\section{Description of Effort}

The planning and initiation phase of the MTA project involved (1) development of the project work plan, (2) selection of a suitable study site location, (3) development of specifications for revegetation procedures to be tested, and (4) establishment of the study site. The objective of each of the four tasks is to provide a better understanding of the procedures needed to rehabilitate training areas.

\subsection{Work Plan Development}

As mentioned in Sec. 2.2, the need for the Minimal Technologies Application project grew out of experience gained from the Range $8 \mathrm{C}$ rehabilitation demonstration project that is still under way at HTA. Observations at Range $8 \mathrm{C}$ indicated excellent vegetation establishment on areas with complete seedbed preparation (i.e., leveling, ripping, tillage,) and drill seeding, but the total cost of these combined operations was DM 4,900 ha-1 ( $\left.\$ 965 \mathrm{acre}^{-1}\right)$. Further, establishment of acceptable ground cover was observed on an area where seed was broadcast without seedbed preparation. Total cost of this revegetation procedure was about DM 1,400 ha-1 $\left(\$ 275\right.$ acre $\left.^{-1}\right)$ because the only expenses were for the seed mixture and broadcast seeding. Other observations at Range $8 \mathrm{C}$ indicate continued military traffic on the site despite measures to exclude vehicles (e.g., construction of tank ditches, installation of boundary markers). It does not appear to be possible or practical to completely close an area during vegetation establishment. These combined observations established the goal of the MTA project - to develop and evaluate revegetation procedures that minimize costs and closure periods during the establishment of adequate ground cover for erosion control in training areas.

\subsubsection{Seedbed Preparation}

The first objective of the MTA project is to determine if seedbed preparation methods and seeding options influence the establishment of aderisiate ground cover for erosion control. The selected methods and options represented a range of costs that reflected the complexity of each; this range was necessary to determine the minimum requirements for establishing adequate ground cover. In addition to direct comparison between individual seedbed preparation methods and seeding options, data from each tested combination would be useful in determining the most effective method for rehabilitating both actively used training ranges and areas closed to vehicle traffic. The four seedbed preparation methods and seeding options selected for evaluation were (1) fertilize and seed; (2) fertilize, seed, and harrow; (3) fertilize, complete seedbed preparation, seed, and harrow; and (4) no seedbed preparation or seed application (i.e., no treatment).

The first method/option employed was fertilization and seeding with no seedbed preparation. This represented minimum cost and complexity because nnly two operations (broadcasting fertilizer and seed) were required. Equipment and time required are minimal, and the seeding option is similar to aerial seeding, which has the potential for use at HTA (aerial seeding is used in the United States to revegetate relatively large areas of disturbed land quickly and at low 
cost). An advantage is that the broadcasting equipment mounted on a tractor or similar equipment to treat large areas in a short time. This equipment can be operated on a wide range of terrain (e.g., ruts, rocks, among trees, wet areas) where other types of seeding and fertilizing equipment cannot be operated.

The second method/option was minimal seedbed preparation and included harrowing after the fertilizer and seed were broadcast. Although harrowing is an extra operation and thus increases the cost, it was necessary to provide plant establishment microsites on smooth or compacted soil surfaces. Minimal seedbed preparation breaks the soil crust on barren areas and roughens the surface of tank trails, problems that are common to many areas at HTA. Areas that can be harrowed are more limited than those that received broadcast fertilizer and seed only because a harrow cannot be used on rocky or wet areas.

The third method/option was complete seedbed preparation and included tillage of tank trails and barren areas, broadcasting of fertilizer and seed, and harrowing. This procedure was used to collect comparative data on a proven revegetation technique and to confirm results of the Range $8 \mathrm{C}$ study. Tillage greatly increases cost, and the areas where complete seedbed preparation can be used are limited because of terrain and potential erosion on steeper slopes where complete seedbeds are prepared. In addition, wet or rocky soils can limit the use and effectiveness of some tillage equipment.

The fourth and final seedbed preparation method/option used neither seedbed preparation nor seed application; it served as a control to determine the type, amount, and rate of vegetation establishment when the only measure is exclusion of military use. The success of this procedure was expected to be low because the natural revegetation rate at Range $8 \mathrm{C}$ was low. However, if adequate ground cover could be established without seedbed preparation or seeding, revegetation costs would be greatly reduced. The only cost involved in this final technique would be that of closing the area for the required period.

A remaining point was to determine the amount and type of soil amendments and seed mixture to be used for this project. A single type and application rate of fertilizer and a common seed mixture and seeding rate were decided for the methods/options requiring these materials. Both fertilization and seeding would be done by broadcast because only one technique included the complete seedbed preparation required for effective operation of a seed drill. The use of a common fertilizer and seed application rate also greatly reduces the number of variables and hence the number of replicate plots and the total area needed for the study. The types and amounts of soil amendments, as well as seeding mixture and seeding rate, were determined during development of contractor specifications.

\subsubsection{Closure Perlods}

The second objective of the MTA project is to determine if the length of the site closure period influences the establishment of adequate ground cover for erosion control at HTA. As with seedbed preparation, a range of closure periods was needed to determine the shortest possible period. Selected periods must be compatible with biological constraints and training requirements. 
At least two to three weeks were needed for seed germination. Closure of areas for extended periods during revegetation would reduce usable training areas at HTA and increase training pressure on the areas that remained open. Closure periods are a compromise between biological requirements and the need to keep most of the HTA open for tactical training. The three closure periods selected for evaluation were (1) two to three weeks, (2) two to three months, and (3) one year.

The first closure period (two to three weeks) was considered the minimal bioiogical requirement. Most grass and legume seeds germinate in three weeks or less, but extensive plant roots necessary for a stable vegetative community are not developed during this short period. The short period fit the training schedule at HTA because two weeks is considered the normal training cycle. Expectations for the success of the short closure period were not high, but it was included because it closely simulated a "no-closure" option.

The second closure period selected (two to three months) represented one growing season. The area would be seeded in the spring and would remain closed until mid- or late summer, allowing ample time for seed germination and development of plant top and root growth. Also, this closure period would limit the area available for training at HTA during about one-third of the year, but it would not affect training during a much longer period.

The third closure period was one year, the longest time considered necessary for adequate vegetation development at HTA. This period provides ample time for establishment and growth of grasses and legumes. Established vegetation is more resistant to vehicle damage and recovers faster than newly established seedlings. This relatively long closure period would allow some plants to mature, set seed, and provide a source for natural reseeding and could increase the time between reseeding cycles at HTA training ranges. The major disadvantage of this closure period is that a revegetation site is unavailable for training for one complete year, adding training pressure to the ranges that remain open.

\subsubsection{Site Plan Development}

The third objective of the study is to evaluate various revegetation procedures (seedbed preparation methods and seeding options combined with a closure period) under field conditions. One technique for combining four seedbed preparation methods with three closure periods is a matrix site design. Seedbed preparation methods are aligned with one axis of the site, and closure periods are aligned with the other axis. This arrangement provides for 12 combinations of revegetation procedures (Fig. 3).

This matrix design has several advantages. Revegetation procedures were to be evaluated under field conditiciis, which imply military use and traffic at the end of each closure period. At the start of the study, the entire area would be closed, but at the end of the first closure period (two to three weeks) the barricade along the time axis would be moved back to the next closure period line. Removal of the barricades at each end of the area would allow normal use of the newly opened area. After two or three months, the barricade along the method axis would be moved back again and the second area would be opened for renewed use. A second major advantage of the 


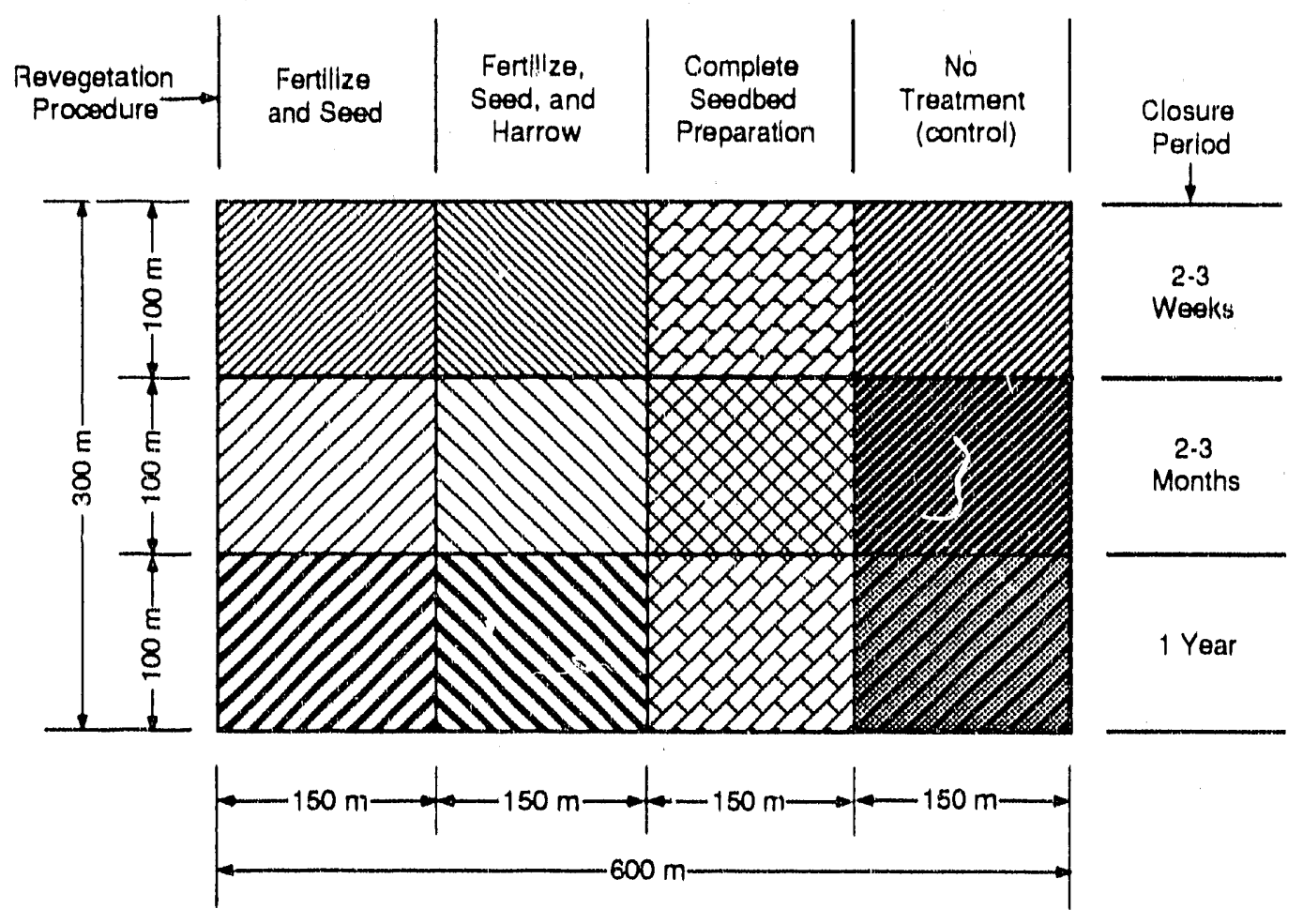

FIGURE 3 Schematic of Matrix Site Design

matrix design is the length of barricade required to exclude traffic. The perimeter length requiring barricades would be greatly increased if individual treatment plots were established in a random pattern. A random plot design could also influence traffic patterns through the study area, preventing normal use.

A disadvantage of the matrix plot design is that individual treatment plot locations cannot be randomly assigned, precluding the validity of standard statistical data analysis from individual plots. However, ANL experience indicates that statistical analysis to determine significant differences among the revegetation procedures may not be necessary to judge and compare the effectiveness of individual revegetation procedures. While statistical analysis of plant cover data may determine subtle differences in the vegetative community, substantial increases and changes in ground cover will be needed for effective erosion control on HTA training areas. Differences between successful and unsuccessful revegetation must be obvious. Superior procedures must be evident, even to the casual observer, by the increased type and amount of ground cover established.

A second important consideration in site plan development was the minimal size of an individual revegetation procedure treatment area. Relatively large individual treatment plots would be required to provide a range of training damage and normal use for evaluating each revegetation procedure. Previous inspections of HTA indicated a range of vegetation damage usually occurring within an area $100 \mathrm{ml}(328 \mathrm{ft})$ square, or 1 ha $(2.5$ acres $)$ in surface area. A treatment plot of one hectare, or larger if possible, would enable the rehabilitation contractor to use the size and type of 
equipment typically required for seedbed preparation and seeding at HTA. This plot size would provide ample space for the establishment of vegetation monitoring transects needed to evaluate vegetation establishment.

\subsubsection{Recommendatlons}

The fourth objective of the study is to develop recommendations for future training area revegetation. This would be accomplished through analysis of the data collected during and after site use.

\subsection{Site Selection}

This was an important task in ti.e MrA study; the site had to be large enough to accommodate the study design. Other factors (soil conditions, vegetation damage, training use) that influence the success or failure of the rehabilitation procedures must be typical of the HTA if the study results are to be useful.

\subsubsection{Site Selection Criterla}

Two site selection criteria had been established during site plan development. Minimum dimensions must be about $300 \mathrm{~m}(1,000 \mathrm{ft})$ - required for three closure periods - by $400 \mathrm{~m}$ for four seedbed preparation methods. An area with these dimensions occupies 12 ha. The second established consideration was that a range of vegetation damage should be present. If possible, individual treatment plots should include one or more of the four classes of vegetation damage (severe, heavy, moderate, and slight). Severe vegetation damage is defined as barren area, such as frequently used tank trails. Heavily damaged areas have scattered clumps of vegetation, but less than $50 \%$ total vegetative ground cover. Morlerately damaged areas have $50 \%$ to $80 \%$ ground cover, and slightly damaged or unolamaged areas have more than $80 \%$ total ground cover. It may not be possible to have the complete range of vegetation damage classes in each individual treatment plot, but severe damage and one other class should be represented in each plot. Further, the vegetative cover should be the typical mixture of forbs, grasses, and legumes found in HTA upland areas.

Additional site selection criteria were uniformity of soil type, topography, and location. Sinilar soil characteristics over the entire study site were needed for accurate assessment of each treatment. Differences in soil fertility or physical properties would be reflected in the vegetation data. If soils in all plots were not similar, vegetation response would be to the soil conditions and not to individual rehabilitation treatments. One factor that influences soil cievelopment and resultant

soil characteristics is topography; uniform topography usually, but not always, indicates similar soil types. Large differences in slopes would also cause the development of atypical traffic patterns. Finally, it is essential that sites be located near a major road to provide access for the revegetation contractor and for monitoring. 
The final site selection criterion was military use of the general area. The study site could not extend across or occupy an entire valley floor or prevent use or access to adjacent areas outside the study. This required that the site be located in a valley more than $300 \mathrm{~m}$ wide. As stated in the third objective, evaluation of revegetation procedures under normal field conditions implies renewed use of the stidy site at the end of each closure period. This objective required that the site be located in an area used frequently for maneuvers and not in an isolated sector of HTA.

The selection criteria were reviewed and, with the assistance of USACERL and staff of the HTA Directorate of Engineering and Housing (DEH), several potential study site locations were identified on an HTA map. An inspection tour was made, and the sites were ranked by the selection criteria; the results indicated that the two most limiting factors for site selection were size and military use of the general area. Several potential sites were too small to accommodate the matrix design of the study. Other, larger, sites were located in sectors of HTA not regularly used for training. The remaining potential sites were ranked, and the final selection was a site in a central valley of HTA about $0.5 \mathrm{~km}$ southeast of the old village of Raversdorf.

\subsubsection{Site Location and Description}

Raversdorf is about $3 \mathrm{~km}$ south of the north boundary of HTA on the Hohenburg Tank Road and $0.5 \mathrm{~km}$ east (Fig. 2). The old village is at the west end of the Hohenburg Drop Zone marke d on HTA maps, in a wide valley extending about $3 \mathrm{~km}$ to the southeast.

The valley here is more than $500 \mathrm{~m}$ wide from tree line to tree line and extends $1 \mathrm{~km}$ or more in each direction, providing ample space for the study site based on the matrix design. Existing ground cover in the valley was mainly a mixture of forbs, with some grasses and legumes, and was typical of HTA meadows. Vegetation damage in the valley and at the site ranged from severe on tank trails to slight or no damage in areas that have not been used by vehicles. Small areas with other classes of vegetation damage were present across the entire valley. The study site's location between the south tree line and the watercourse about $400 \mathrm{~m}$ to the north has a gentle slope, indicating a uniform soil type. This location is also within $0.5 \mathrm{~km}$ of a gravel road and $1 \mathrm{~km}$ of the Hohenburg Tank Road, thus providing access for the rehabilitation contractor and for monitoring.

The valley width provided sufficient space for the study site with a wide corridor along the north side for maneuvers through the valley and access to adjacent areas. A few small forest plots stood near the watercourse on the noi hern side of the valley, but these plots were outside the study area and would not impede vehicle traffic through the valley. With the matrix study-site design, the four seedbed preparation methods could be randomly located perpendicular to the tree line and the three closure periods could be parallel with the tree line. Assigning the shortest closure period along the north edge and nearest the valley center meant that the corridor through the valley would widen as the site was opened for use. This would allow normal use and traffic on reopened closure-period segments, as required by the study design. 
This site met all the selection criteria developed for the study. Discussions with HTA Range Control indicated that the site could be closed for the study without disruption to normal training. With site selection completed, work began on development of contractor specifications.

\subsection{Specification Development}

Specifications for the rehabilitation contract included (1) detailed information on the type and application rate of soil amendments, (2) plant species included in the seed rixixture and seeding rate, and (3) descriptions of each rehabilitation operation and of equipment necessary to perform required operations. Project specifications were developed by reviewing available data on typical soil conditions at HTA, obtaining information on rehabilitation plant species approved and available for use in West Germany, and using ANL staff expertise in rehabilitation seedbed preparation and equipment requirements. Detailed specifications were necessary to ensure that the rehabilitation treatments would be installed as planned and to provide a base for bidding on the rehabilitation contract.

\subsubsection{Soll Amendments}

No specific information is available on the physical properties and chemical characteristics of soils at the MTA study site and at HTA in general. A detailed soil survey of HTA has not been conducted by the Bavarian Agricultural Agency because HTA has been removed from agricultural production and under the control of the U.S. military for a number of years. Collection and analysis of soil samples from the MTA site was not possible because analysis could not be completed in the short period between site selection and preparation of contractor specifications. Site inspection revealed that the physical properties of the soil were similar to those of soils found in the upland meadow of Range 8C. The soils had been analyzed in the Technical University of Munich soils analytical laboratory at Weihenstephan, and these data were used as a general guide for determining soil amendments for the MTA site.

Results of this analysis of surface soils from the Range 8C meadow area are given in Table 1. Soil $\mathrm{pH}$ ranged from 7.2 to 7.4 , with a mean of 7.32 . The accepteci $\mathrm{pH}$ range for establishment and growth of grasses and legumes is 6.5 to 7.5 ; therefore, adjustment of soil pH by adding limestone was not necessary. Soil $\mathrm{P}_{2} \mathrm{O}_{5}$ levels were considered low, averaging only $10 \mathrm{mg} \mathrm{kg}^{-1}$ (4.37 $\mathrm{mg} \mathrm{kg}^{-1} \mathrm{P}$ ), indicating that addition of this essential plant nutrient was needed for plant establishment and good root growth. The mean $\mathrm{K}_{2} \mathrm{O}$ level of $120 \mathrm{mg} \mathrm{kg}^{-1}$ $(99.6 \mathrm{mg} \mathrm{kg}-1 \mathrm{k}$ ) was considered intermediate, which suggests a potential response to potassium fertilization. The relatively high level of organic matter (averaging about $4 \%$ ) indicated that nitrogen would be available for plant growth over an extended period. The low phosphorus and intermediate potassium levels pointed out the need for some type of fertilizer.

Information provided by the soil analytical laboratory at Weihenstephan indicated that an application of 20 to $40 \mathrm{~kg} \mathrm{ha}^{-1}$ of $\mathrm{P}_{2} \mathrm{O}_{5}$ fertilizer was needed for grasses and legumes on areas similar to those at the MTA site. On the basis of this information, it was determined that $25 \mathrm{~kg} \mathrm{ha}^{-1}$ of $\mathrm{P}_{2} \mathrm{O}_{5}$ fertilizer would be applied as part of the revegetation technique. Application of a complete 
TABLE 1 Analytical Results and Means of Surface Solls from the Range 8C Project Site

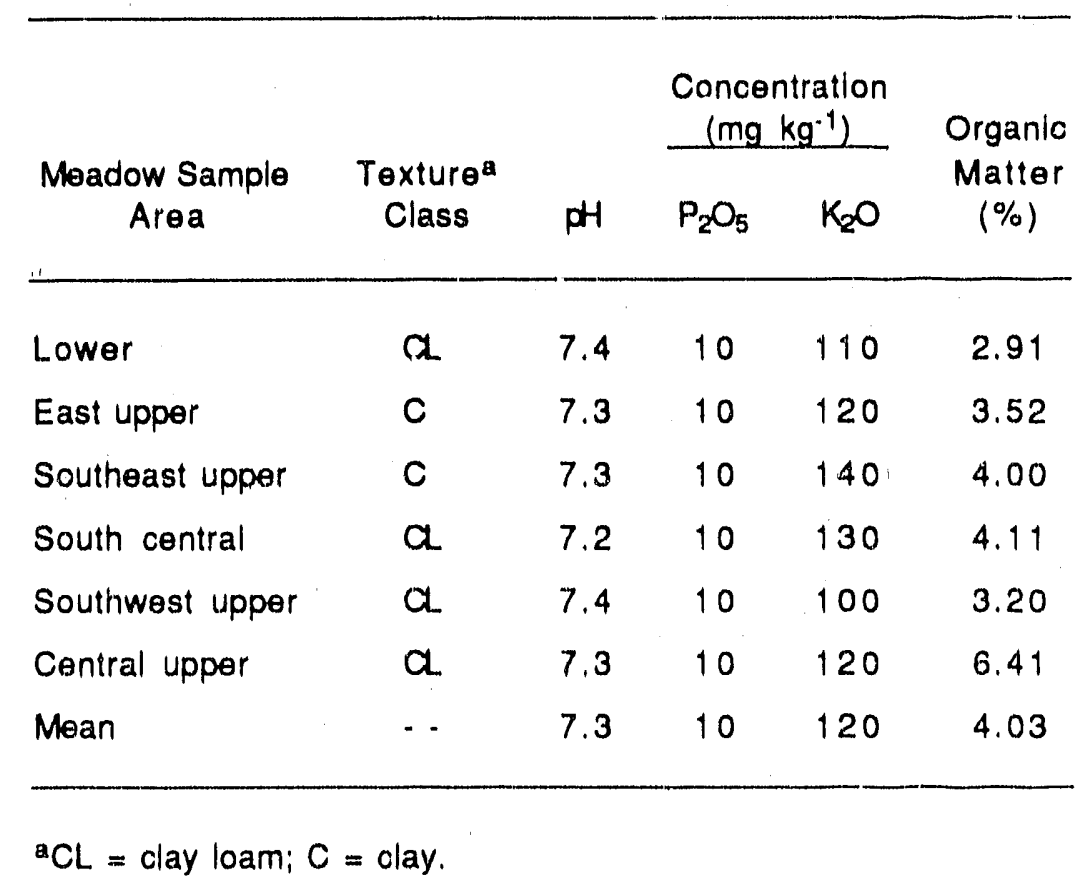

fertilizer containing all three major plant nutrients would aid in plant establishment and growth because nitrogen and potassium would also be more available during the critical period of early plant growth. Costs of applying a complete fertilizer containing nitrogen, potassium, and phosphorus are about the same as applying a fertilizer material containing only phosphorus. The increase in cost for the complete fertilizer compared with the phosphorus fertilizer only was small compared with the cost of applying the fertilizer. Therefore, it was decided that a complete fertilizer to supply $25 \mathrm{~kg} \mathrm{ha}^{-1}$ each of nitrogen, $\mathrm{P}_{2} \mathrm{O}_{5}$, and $\mathrm{K}_{2} \mathrm{O}$ would be used on all areas that were to receive fertilizer.

\subsubsection{Seed Mixture}

The initial task in selecting plant species for the seed mixture was development of species selection criteria. Factors used to generate the selection criteria were (1) knowledge of site conditions, (2) past revegetation experience, (3) observations of the Range $8 \mathrm{C}$ rehabilitation project, and (4) approval by Bavarian officials. Species selected for the seed mixture were to meet the following criteria:

- Adapted to the local climate.

- Adapted to site soil conditions.

- Approved for use by Bavarian officials. 
- Available locally at reasonable cost.

- Grasses to be sod formers for erosion control.

- Rhizomatous or vegetative reproduction.

- Rapid establishment and growth.

- Tolerance to vehicle traffic.

The seed mixture listed in 'Table 2 was generated on the basis of the selection criteria and information collected in planning the Range $8 \mathrm{C}$ project. Several grass species met all selection criteria, and all species in the mixture met the first three and two or more of the remaining five criteria. A mixure of five grasses and two legumes was used to provide a diverse vegetative community. One or more species were included in the mixture tu occupy the range of microconditions that existed at the site. For example, reed canarygrass is adapted to wet and poorly drained soils, while smooth brome and creeping red fescue are better suited to dry or infertile soils. While both legumes are suited to moist soils, birdsfoot trefoil will tolerate droughty conditions. Cereal rye is in the mixture to provide ground cover for erosion control while the perennial species became established.

A derise stand of grasses and legumes is needed to protect the soil surface and control erosion. A thick stand of alfalfa has about 325 plants per square meter $\left(20\right.$ plants $\mathrm{ft}^{-2}$ ) during the seeding year (University of Illinois 1976). It is common for no more than one-third of the sown

TABLE 2 Seed Mixture and Seeding Rate Used at the MTA Site

\begin{tabular}{llrrr}
\hline & & \multicolumn{3}{c}{ Seedlng Rate } \\
\cline { 3 - 5 } \multicolumn{1}{c}{ Spacies Name } & Common Name & $\begin{array}{c}\text { Seeds } \\
\left(\mathrm{g}^{-1}\right)\end{array}$ & $\begin{array}{c}\mathrm{kg} \\
\left(\mathrm{ha}^{-1}\right)\end{array}$ & $\begin{array}{r}\text { Seeds } \\
\left(\mathrm{m}^{-2}\right)\end{array}$ \\
\hline Agropyron repens & Quackgrass & 243 & 7.0 & 170 \\
Bromus inermis & Smooth bromegrass & 300 & 6.0 & 180 \\
Dactylis glomerata & Orchardgrass & 1,442 & 1.5 & 216 \\
Festuca rubra rubra & Creeping red fescue & 1,356 & 1.5 & 203 \\
Phalaris arundinacea & Reed canarygrass & 1,175 & 1.5 & 176 \\
Lotus corniculatus & Birdsfoot trefoll & 827 & 5.0 & 413 \\
Tritolium repens & White clover & 1,764 & 3.0 & 529 \\
Scale cereale & Rye & 40 & 50.0 & 200 \\
Total & & $\ldots$ & 75.5 & 2.087 \\
\hline
\end{tabular}


seed to produce a seedling and for only about one-half of the seedlings to survive the first year (Decker et al. 1973). On the basis of these values, 1,950 seeds $\mathrm{m}^{-2}$ must be sown to produce a dense stand of 325 plants $\mathrm{m}^{-2}$ at the end of the first year. This density was used to calculate the seeding rate for the MTA site. The total number of seeds required was divided by two, representing grasses and legumes. About 195 or more seeds of each of the five grass species were needed in the mixture for each square meter. The number of kilograms of seed required for each hectare was calculated by multiplying by 10 the number of seeds required and dividing the product by the number of seeds of the species per gram. Some adjustment in seed weight was made to provide for practical measurement of seed size and texture. About 485 legume seeds $\mathrm{m}^{-2}$ of each species was required, and this same procedure was used for the legume species. Cereal rye was not included in the calculation because it is an annual included in the mix to provide erosion control during perennial establishment.

\subsubsection{Preparation of Specifications}

Rehabilitation and equipment requirements were established during development of the project work plan, along with selection of seedbed preparation methods and seeding options. All operations planned for the MTA site had been performed at Range 8C, and appropriate sections of the old specifications were reviewed, modified if necessary, and used during the preparation of the new MTA specifications. A detailed description was prepared for each operation, including material and equipment requirements and the sequence of operations to be carried for each of the three methods. Drawings of the site, lists of required materials, general conditions of the contract, and detailed instruction for bidding on the project were generated. This material was assembled and translated into German after a review by USACERL. A complete set of specifications is provided in App. A.

A detailed method for evaluating contractor bids was also developed. Included in the evaluation were the bid price, project schedule, material costs, equiprnent and personnel to be used, and a history of rehabilitation projects completed by the bidder. A complete bid package is provided in App. B.

\subsection{Site Establishment}

The study work plan was finished and the study site location was determined in March 1987. Copies of the German-language specifications were sent to five prospective bidders by the end of April. Three bids were received by the bid closing date of 29 Mily 1987 and evaluated with the procedure described in the bid package; the revegetation contract was awarded on 3 June. Installation of the revegetation procedures was scheduled to begin on 8 June 1987.

Establishment of the study site involved five tasks: (1) physical marking of the boundaries of the treatment plots, (2) installation of concertina wire to exclude traffic from the site, (3) collection of soil samples, (4) establishment of the vegetation monitoring transects and collection of initial plant cover data, and (5) supervision of the rehabilitation contractor during 
seedbed preparation and seeding operations. These tasks began in eurly June and were completed during the last week in June.

\subsubsection{Site Layout}

In early June 1987, ANL staff members arived at HTA to lay out the study site. The military community at HTA had several concerns about the location and size of the proposed study site. Plauned maneuvers required unrestricted travel through a large part of the valley during the coming summer months. To proceed with the study on schedule, the site was moved across the valley from its original location. The new location provided a wide unrestricted corridor through the valley without forest plots or the watercourse. The original rectangular shape of the study site was also changed to a parallelogram shape, which together with a reduction in the width of the three closure period plots from $100 \mathrm{~m}$ to $75 \mathrm{~m}$, decreased the width of the site by about $185 \mathrm{~m}$. This new shape did not alter the matrix design of the study site, but it did reduce the area cf each treatment segment from 1.50 ha to 1.12 ha. The smaller treatment areas would still provide ample space for conventional rehabilitation equipment and for the monitoring transects.

The new location was similar to the original location with respect to soil type, topography, and general location. However, there were three notable exceptions: (1) seven small forest plots were in the new site, (2) the main watercourse in the valley ran through the new location, and (3) a huavily used gravel trail ran inside and parallel to the north edge of the site. The forest plots and watercourse would have little influence on installation of the revegetation procedures but could disrupt normal traffic through the site after removal of the barriers. The gravel trail traversed the one-year closure period, and soil conditior 3 could affect vegetation growth on the trail. While the new location had several disadvantages, the study proceeded because contract arrangements with the rehabilitation contractor had already been completed.

The relocated study site was laid out by establishing the northeast corner near the intersection of Raversdorf Road and north of the tree line in the valley (Fig, 4). The southeast corner was established by extending a line from the northeast corner parallel to the tree line for $600 \mathrm{~m}$ to the east-southeast. The northwest corner was then established by extending a line from the northeast corner $225 \mathrm{~m}$ to the west-northwest parallel with Raversdorf Road. The southwest and fourth comer was established by measuring the appropriate distances from the northwest and southenst corners. The corners of each treatment area bordering the outsicle edge of the study site were determined by measuring the appropriate distance along the site boundary. The six interior corners of the plots were sighted in and marked, and the distances were checked by measuring.

Above-normal rainfall had occurred at HTA for several weeks before layout of the site. Because the site was in the lowest part of the valley floor with the main watercourse, many small areas had standing water. Other larger areas had been heavily used for maneuvers during the wet weather and had deep ruts with standing water. These muddy and wet conditions prolonged the relatively simple task of site layout to several days; this was a foretaste of problems to be encountered in establishing the MTA study site. 


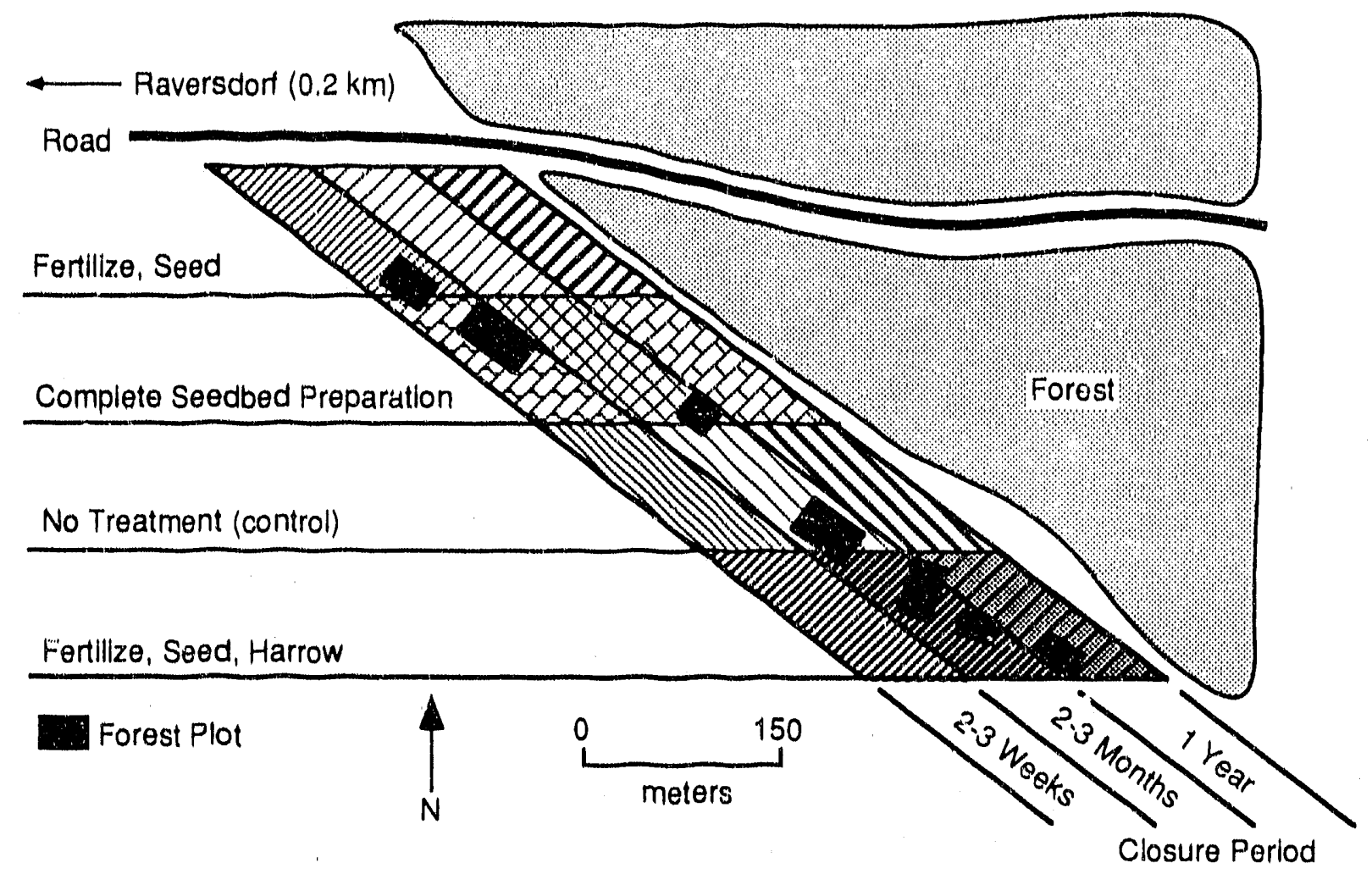

FIGURE 4 Planned Design for the Relocated Study Site

\subsubsection{Fence Construction}

Observations at the Range $8 \mathrm{C}$ site revealed difficulty in preventing vehicle trespass during revegetation. Tank ditches had been dug across open ends of Range $8 \mathrm{C}$ and warning signs were erected on the boundary, but both measures were ineffective in keeping vehicles out of the site. The one effective method was placement of concertina wire along site boundaries. Results of the MTA study depended on keeping traffic out for a predetermined period, and use of concertina wire was the best method available. There were two other advantages to using concertina wire as a barrier. First, it was available at HTA; second, it could be moved or removed without major environmental impact. During work plan deve opment, the Directorate of Engineering and Housing (DEH) indicated that HTA would provide both the wire and the labor to install and move the wire during the study.

A German labor crew from DEH installed a triple strand of concertina wire on the perimeter of the MTA site. Two strands of wire were laid side-by-side on the ground and the third strand was placed on top of the other two. Almost $5 \mathrm{~km}$ of wire was needed for the 1650 -m perimeter of the site. Signs indicating closure of the area were also erected at $25-\mathrm{m}$ intervals outside the concertina wire fence. Installation of the wire was very labor-intensive, requiring more than 400 person-hours of labor. The wet and muddy conditions at the site (Fig. 5) may have slowed installation of the wire and signs, but even with ideal conditions, the job would have been laborintensive. 


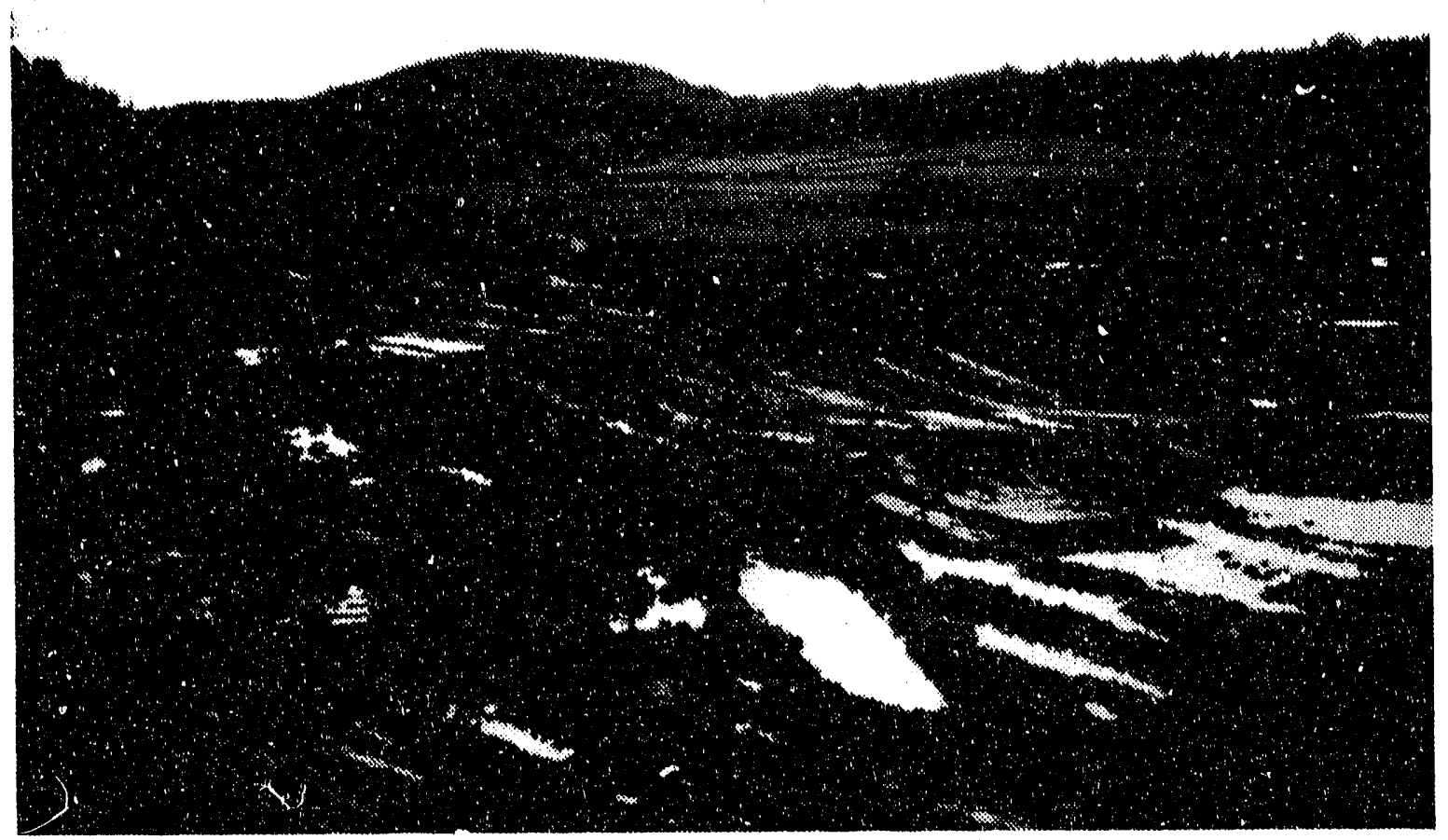

FIGURE 5 View of Study Site during Fence Construction, Mid-June 1987

\subsubsection{Soll Sample Collection}

Following installation of the concertina wire, a composite soil sample was collected from each treatment area. Analytical results of these samples would be used to compare the physical and chemical characteristics of the soil from the 12 individual treatment areas. If soil properties from all the areas were similar, differences in vegetation growth would be due mainly to seeding and seedbed preparation. If soil properties were significantly different, adjustment of the vegetation data could be necessary.

During soil sampling, seven to ten 2.5 -cm-diameter soil cores, to a depth of about $15 \mathrm{~cm}$, were collected from random locations in each plot. Subsamples were combined in a common container, mixed, and a representative sample removed for analysis. Soil samples weia bagged and forwarded to the soil analytical laboratory at the Technical University of Munich. The measured parameters were soil texture, $\mathrm{pH}$, available phosphorus, available potassium, and organic carbon (Table 3). A detailed discussion of the results, differences between areas, and the influence of soil properties on plant growth will be provided in a second publication on the project. 
TABLE 3 Analytical Results and Means of Surface Soils from the Study Site

\begin{tabular}{|c|c|c|c|c|c|}
\hline \multirow[b]{2}{*}{ Area } & \multirow{2}{*}{$\begin{array}{c}\text { Textureb } \\
\text { Class }\end{array}$} & \multirow[b]{2}{*}{ pH } & \multicolumn{2}{|c|}{$\begin{array}{c}\text { Concentration } \\
\left(\mathrm{mg} \mathrm{kg} \mathrm{kg}^{-1}\right)\end{array}$} & \multirow{2}{*}{$\begin{array}{c}\text { Organic } \\
\text { Matter } \\
(\%)\end{array}$} \\
\hline & & & $\mathrm{P}_{2} \mathrm{O}_{5}$ & $\mathrm{~K}_{2} \mathrm{O}$ & \\
\hline FS-Y & $C$ & 7.5 & 10 & 90 & 2.16 \\
\hline FS-M & $\mathrm{C}$ & 7.4 & 10 & 80 & 1.58 \\
\hline FS-W & $a$ & 7.4 & 30 & 90 & 2.89 \\
\hline COM-Y & Sic & 7.4 & 10 & 110 & 2.77 \\
\hline COM-M & $\mathrm{SiC}$ & 7.4 & 10 & 90 & 2.69 \\
\hline COM-Y & Sic & 7.3 & 10 & 100 & 3.35 \\
\hline NT-Y & $\mathrm{SiC}$ & 7.6 & 10 & 90 & 2.28 \\
\hline$N T-M$ & $a$ & 7.4 & 30 & 100 & 3.25 \\
\hline NT-W & $\mathrm{SiC}$ & 7.3 & 20 & 110 & 4.03 \\
\hline FSH-Y & C & 7.5 & 10 & 80 & 1.85 \\
\hline FSH-M & $\mathrm{SiC}$ & 7.2 & 20 & 100 & 3.16 \\
\hline FSH-W & $\mathrm{SiC}$ & 7.3 & 40 & 120 & 3.96 \\
\hline Means & $\ldots$ & 7.4 & 17.5 & 96.7 & 2.56 \\
\hline
\end{tabular}

\footnotetext{
aFS = fertilize and seed; COM = complete; NT $=$ no

treatment; $F S H=$ fertilize, seed, and harrow; $Y=$ year;

$M=$ month; $W=$ week.

${ }^{b} \mathrm{C}=$ clay, $\mathrm{CL}=$ clay loam, $\mathrm{SiC}=$ silty clay.
}

\subsubsection{Transect Establishment}

To determine which of the 12 revegetation procedures was the most effective for establishing ground cover at HTA, exposed soil and amount and type of vegetation establishment would be measured in each of the 12 plots. One approach in determining ground cover is the point-intercept method (Chambers and Brown 1983), which uses a point frame. Surface conditions and/or vegetation type are identified and recorded for a number of points along an established line or transect. These data are summarized and used to characterize the surface condition and the amount and type of vegetation on the transect. Data from several transects are used to determine plot conditions and relative effectiveness of revegetation procedures.

At the MTA site, a random point that could be relocated for future monitoring periods was first established. A line or transect from the starting point through an area with similar cover conditions is established, and the compass heading of the transect is recorded. At 1-m intervals, the point frame is placed perpendicular to the transect. The frame is $1.5 \mathrm{~m}$ long and has 10 points or pins on $10-\mathrm{cm}$ centers and a $30-\mathrm{cm}$ space at each end. Surface condition (exposed soil or litter) ur vegetation by type (grass, legume, or forb) is recorded at the initial contact of the pin. Evidence of recent vegetation damage by vehicle traffic is also noted. Ground cover data from 10 frame 
settings on alternate sides of a 9-m transect provides 100 observations. These data represent the surface conditions and vegetative cover from a transect or sampling belt $3 \mathrm{~m}$ wide and $9 \mathrm{~m}$ long. Three transects were established in each revegetation technique area.

All transects in each revegetation plot were located in areas without plant cover because the relative effectiveness of the revegetation procedure in establishing new vegetation was to be measured. Locating the transects was relatively simple because of the general lack of vegetative cover on several areas in each plot. Data collection was also relatively simple because bare ground or exposed soil surface was encountered on almost all the points on each of the 36 transects.

\subsubsection{Contractor Activities}

Above-average rainfall during May and the first three weeks of June made it impossible to prepare the seedbed and carry out the seeding. The scheduled starting date of 8 June 1987 was delayed as the rain continued. Runoff saturated the heavy-textured soil, and vehicle traffic on the wet site created deep ruts in many areas. Deep ruts and low spots filled with water and became small ponds, while the lack of ground cover on large parts of the site caused the surface soil to become sticky mud. These conditions prevented the rehabilitation contractor from beginning work until the rain had stopped and the surface had dried.

Installation of the rehabilitation procedures was delayed until the last week of June, following a week without rain. The surface had dried, but many of the deeper ruts and low spots still had standing water. While these conditions hampered seedbed preparation and seeding, they are typical of many of the heavily used training ranges at HTA during the spring and early summer.

Broadcast application of the fertilizer and seed mixture at the prescribed rates was slowed by the rutted conditions of the site; these operations were completed on the fertilize and seed only areas and on the fertilize, seed, and harrow treatment areas. Harrowing was attempted on the latter area, but the rutted surface and standing water prevented the intended results on large portions of the area.

The revegetation procedure requiring complete seedbed preparation was most affected by the wet arid rutted site conditions. A lack of proper equipment to carry out the required operations added to the problem. The contractor's equipment lacked the power to prepare the seedbed as specified. The tillage implement, a rototiller mounted on the rear of a Unimog, was underpowered and could not be used on rutted areas. Fertilizer and the seed mixture were applied, but complete seedbed preparation had not been accomplished as specified. Harrowing was again tried, but without success. Following four days of effort, the contractor gave up and moved his equipment off post.

This failure on the part of the rehabilitation contractor modified the design of the study. Four revegetation techniques had been planned: (1) fertilization and seeding; (2) fertilization, seeding, and harrowing; (3) complete seedbed preparation with fertilization and seeding; and (4) no treatment. In effect, only the first and last of these were completed (no contractor effort was required for the control, or no-treatment, plots). Thus, only two revegetation procedures are 
represented at the site: (1) broadcast fertilization and seeding and (2) control. Figure 6 shows the arrangement of the two revegetation procedures being tested in the MTA study.

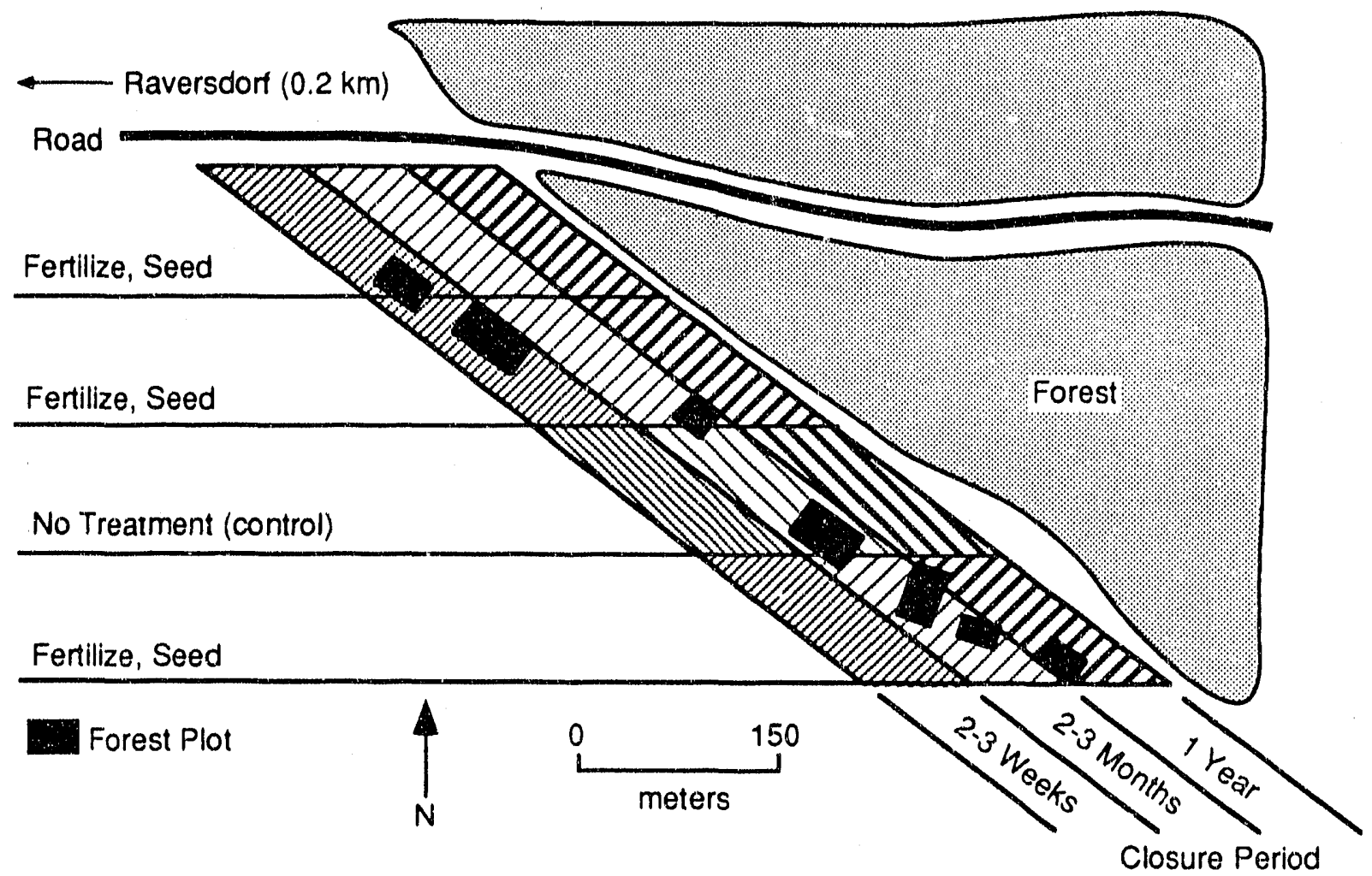

FIGURE 6 Actual Design of Study Site 


\section{Revegetation Costs}

Three bids were received from German rehabilitation contractors for seedbed preparation and seeding at the MTA site. Bid prices ranged from DM 101,000 to DM 42,000 (\$57,70024,000 ), for an average of about DM 65,000. The two lower bids differed by about DM 10,000, while the third was much higher. If the highest bid is disregarded, the average bid drops to about DM 47,000. While bid price was not the only factor in awarding the contract, it became the most important factor because of the wide range in bids. Details of the method used for evaluating bids and awarding the contract are given in App. B.

One requirement for submitting a bid was a listing of the price per hectare for installation of the three seedbed preparation and seeding operations and the price of the the seed mixture. Bid prices for the seed mixture and one seedbed preparation method (fertilizing, seeding, and harrowing) were about the same in the two lower bids. The largest difference between the two lower bids was DM 3,200 ha-1 for the complete seedbed preparation. The major difference in the bid price was due to the size and type of tillage equipment; this difference may have been a major factor in the failure of the contractor - the low bidder - to complete the required tillage successfully. The other major difference between the two low bids was for fertilizing and seeding. Here the bidders were reversed, with the lowest bid at DM 2,600 ha-1 and the intermediate bid at DM 1,800 ha $^{-1}$. On the basis of cost data collected for the Range $8 \mathrm{C}$ project and other ANL rehabilitation projects, the bidder submitting the intermediate bid may have had a better understanding of the equipment requirements and costs involved in seedbed preparation.

Bid prices of the rehabilitation contract awarded for the MTA site are given in Table 4. For several reasons, costs listed in the table are not considered representative of actual or expected costs for revegetation at MTA. The contract was established before the site location was changed, and the areas of the three seedbed preparation and seeding options were not revised from the original contract's 4.5 ha to the actual 3.38 ha. 'Two of the three required seedbed preparation operations were not completed as specified, and the contractor agreed to an adjustment in the costs for those two areas. The aforementioned problems indicate that the rehabilitation contractor has a poor understanding of the equipment requirements for complete seedbed preparation and typical HTA working conditions.

To provide more realistic cost information for future revegetation efforts, additional cost estimates were developed by the ANL staff (Table 5). These estimates were based on other bids received for the MTA project, estimated 1987 material cosis, and additional information from other rehabilitation projects under way in Germany. This information represents the approximate costs that could be expected for similar revegetation efforts at HTA. 
TABLE 4 Bid Prices and Actual Contract Costs for Seedbed Preparation and Seed at the MTA Site (10 0 DM)

\begin{tabular}{|c|c|c|c|c|c|}
\hline \multirow[b]{2}{*}{ Operation } & \multirow[b]{2}{*}{ Quantity } & \multicolumn{2}{|c|}{ Bid Price } & \multicolumn{2}{|c|}{ Actual Cost } \\
\hline & & Unit & Total & Unit & Total \\
\hline Fertillze and seed & 4.5 ha & 2.6 & 11.7 & 2.6 & 11.7 \\
\hline Fertilize, seed, and harrow & $4.5 \mathrm{ha}$ & 2.8 & 12.6 & 2.6 & 11.7 \\
\hline $\begin{array}{l}\text { Deep tillage, fertilize, seedbed } \\
\text { preparation, seed, and harrow }\end{array}$ & $4.5 \mathrm{ha}$ & 3.3 & 14.85 & 2.6 & 11.7 \\
\hline Seed mixture & $1,020.0 \mathrm{~kg}$ & $2.8^{\mathrm{a}}$ & 2.85 & $2.8^{\mathrm{a}}$ & 2.85 \\
\hline $14 \%$ value-added tax & $\cdots$ & $\cdots$ & 5.88 & $\cdots$ & 5.31 \\
\hline Total & & & 47.88 & & 43.27 \\
\hline
\end{tabular}

aDM per kilogram.

TABLE 5 Estimated Representative Revegetation Costs for Hohenfels Training Area

\begin{tabular}{lrr}
\hline & \multicolumn{2}{c}{ Costs per Unit } \\
\cline { 2 - 3 } \multicolumn{1}{c}{ Operation and Material } & DM ha-1 & \$ Acre-1 \\
\hline Deep tillage or ripping & 2,000 & 465 \\
Seedbed preparation (rototilling) & 2,000 & 465 \\
Fertilizer (12-12-12, 208 kg ha-1) & 208 & 48 \\
Broadcast application of fertilizer & 800 & 185 \\
Seed mixture (same species and rate as MTA) & 210 & 49 \\
Broadcast application of seed & 800 & 185 \\
Harrowing & 800 & 185 \\
14\% value-added tax & 955 & 151 \\
Total & 7,773 & 1,733 \\
\hline
\end{tabular}

${ }^{\mathrm{a} D M} 1.75=\$ 1.00 ; 1.00 \mathrm{ha}=2.47$ acres. 


\section{Observations and Recommendations}

Monitoring the establishment and development of vegetative ground cover at the MTA site will provide data needed to determine which revegetation procedure is the most effective in controlling erosion. Planning the study and developing the contractor specifications, as well as observations made during establishinent of the study site, can be added to the data base of the ITAM program. The following observations and suggestions by ANL, based on the experience and knowledge gained from the MTA project, can be used to improve future revegetation projects.

One element of the planning process that could be improved is the time period between site selection and development of contractor specifications. Additional time should be allowed to collect and analyze soil samples from the site. Most HTA solls have similar physical and chemical characteristics, but analyses of soil from the site to be revegetated could be used to refine soil amendments requirements. The difference between success and failure in establishing vegetation can be the type and amount of soil arnendments applied. Soil analysis costs are low compared with the potential saving in soil amendment costs.

Collection of information on cost and availability of seed from local sources before specifications are finalized would reduce seed mixture costs. A large number of seed sources and individual species are available in West Germany, but seed cost for an individual species is dependent on supply and location, which varies widely frorn year to year. Important factors to be considered during the development of a seed mixture and seeding rate are as follows: (1) inclusion of one or more species to be adapted to the various microconditions (i.e., small areas of poorly drained, droughty, or infertile soils) of the site to ensure complete revegetation, (2) selection of individual species to include availability and cost from local sources, (3) planting of 2,000 or more total seeds per square meter to ensure an acceptable stand, and (4) inclusion of one species to provide quick cover for erosion control. Experience indicates that seeding at a high rate is more effective than reseeding in establishing an acceptable vegetation stand.

As part of the planning process, a potential site should be observed during several seasons (spring, summer, and fall), or a full year if possible. The amount and type of vegetation changes that occur each season, the areas to be seeded, and the seedbed preparation methods are dependent on existing ground cover. Site conditions also change throughout the year. The effectiveness of many seedbed preparation methods and seeding options are dependent on soil conditions. Potential problems can be avoided if site conditions are known in advance. If the very wet conditions at the MTA site had been anticipated, alternative seedbed preparation methods may have been specified. A second alternative would have been to delay seedbed preparation and seeding until a drier season of the year.

Selection of the rehabilitation contractor is vital to the success of any revegetation effort. The method developed for evaluating bids for the MTA contract was heavily weighted by costs; this resulted in awarding of the contract to the lowest, but not necessarily the most qualified, bidder. The type and size of equipment available for use during the project was considered, but was not a major factor in awarding the contract. It is strongly suggested that future methods of 
evaluating bids and awarding contracts place increase emphasis on the equipment to be used and on bidder experience.

The final observation involves site closure. Several methods have been used, but concertina wire appears to be the most effective. Installation of the wire is labor-intensive and adds to overall revegetation costs. Closure for revegetation also disrupts normal use of the area. Therefore, new revegetation methods that do not require site closure must be developed and tested. 


\section{Continuation of Monitoring}

The objective of vegetation monitoring at MTA is to provide data for comparing the relative effectiveness of the revegetation procedures tested in this study. Monitoring began before seedbed preparation and seeding and will continue for two years. This data collection period is needed to provide information from all revegetation procedures for one year following reuse of the site. Data on ground cover and surface conditiuns will be collected each spring, summer, and fall to record seasoual changes in the vegetative community.

A visual record of site condition and cover development is being compiled through photographs and videotapes. Photodocumentation began during site selection and will be continued during each monitoring session at the site. Photos and videotape will be used as a part of the technology transfer portion of the study.

The continued monitoring of the establishment, development, and survival of vegetative ground cover at the site for the next two years, combined with seedbed preparation costs and disruption of training caused by site closure, will provide data for determining the most effective revegetation procedure. This information will be of great value in the planning and execution of future rehabilitation efforts at Hohenfels Training Area and other installations with similar soil and climatic conditions. 


\section{References}

Chambers, J.C., and R.W. Brown, 1983, Methods for Vegetation Sampling and Analysis on Revegetated Mined Lands, U.S. Department of Agriculture, Forest Service, Intermountain Forest and Range Experiment Station, General Technical Report INT-151, Ogden, Utah.

Decker, A.M., T.H. Taylor, and C.J. Willard, 1973, Establishment of New Seedlings, in Forages: The Science of Grassland Agriculture, Third Ed., M.E. Heart, D.S. Metcalfe, and R.F. Barnes, eds., The Iowa State University Press, Ames, lowa, pp. 384-395.

University of Illinois, 1976, Illinois Agronomy Handbook, 1977-78, College of Agriculture/Cooperative Extension Service Circular 1129, Urbana, Ill.

Zellmer, S.D., et al., 1987, Argonne National Laboratory and U.S. Army Corps of Engineers, Construction Engineering Research Laboratory, unpublished information. 
Appendix A:

Specifications for Minimal Technologies Application Rehabilitation Project 
SPECIF LCATIONS

FOR

MINIMUM TECHNOLOGY APPLICATIONS RELABILITATION PROJECT HOHENFELS TRAINING AREA, HOHENTELS, WEST GERMANY

English

by

Renewable Resources Section

Energy and Environmental Systemg Division

Argonne Natlonal Laboratory

May 1987

prepared for

United States Army Corps of Englneers

Construction Englneerlang Regearch Laboratory

Champatgn, I1Linois 


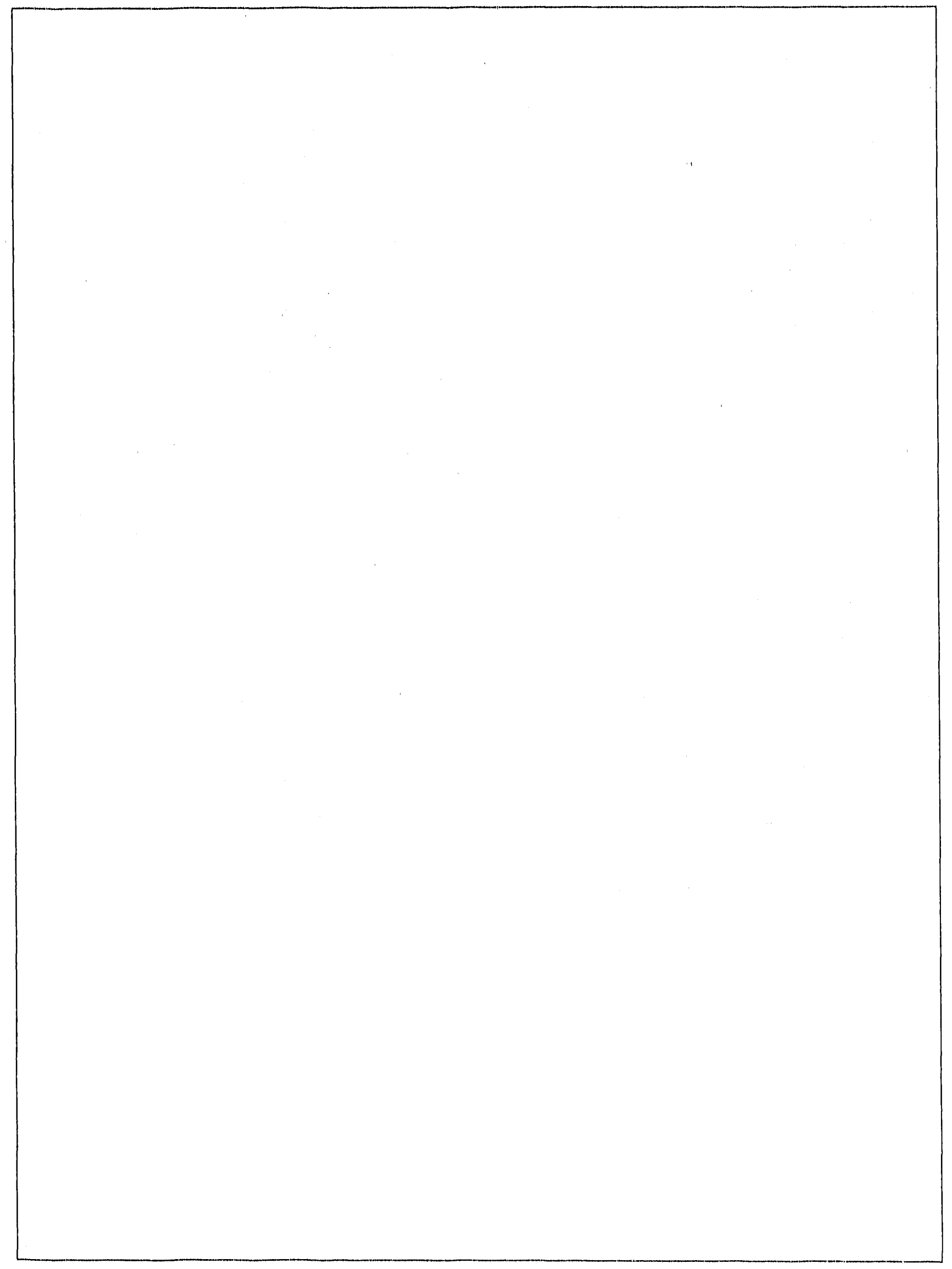

- 


\section{NOTLCE TO BIDDERS}

The following specifications are for the Minimum Technology Applications Rehabilitation Project, Hohenfels Training Area, Hohenfels, West Germany. These specificarions, drawings, and tables are intended to describe the work required to complete the habilitation effort. The bidder shall take no advantage of any appe-ent error or omission in the specifications or drawings and the resident engineer shall be permitted to make such corrections and interpretations as may be deemed necessary for the fulfillment of the intent of the specifications and drawings.

Requirements occurring in all categories in the specifications are binding and the size of the areas and amounts of materials within each category are established. For these reasons bidders are advised to examine the site and the rehabilitation specifications carefully before submitting a bid. For access to the site and questions regarding the specifications contact:

\section{Ms. Hinifred Hodge}

\section{U.S. ARMY CONSTRUCTION ENGINERRING RESEARCH LABORATORY ATTN: Directorate of Engineering and Housing HOHENFELS TRAINING AREA Bullding 13 \\ Phone: 09472-83-2025 ask for 78}

Bidders should subrit a single bid price for all necessary supplies and materials, use of equipment, implements and tools, and labor and crained operators, and other associated costs to complete the project requirements as described in this document. Bids must be submitted in the form of Tables 1 and 2 as shown on pages 3 and 4 of the bid package.

In addition, all bids must include the following information:

1. A tine schedule for the rehabilitation effort. This schedule nust include the starting date of the rehabilitation effort, estimaced period of tine needed to complete each work section and final completion date.

2. A listing of major equipment and implements that are avaliable and w11 be used during the rehabilitation effort.

3. A listing of job categorles and number of individuals that are avallable and will be employed on this job.

4. A list of rehabilitation or similar jobs (location, size, type of work involved, name and phone number of peison to contact) that have been completed during the past two years by your company.

All of the above 1tems, in addition to the bid price, will be considered in the awarding of the contract. 
Sealed bids for the rehabilitation work described in the attached specifications must be received no later than 5:00 pm., Friday May 29, 1987, by:

Mr. Robert P. Houghton SSD-PRO 201, Rm. 235

Argonne National Laboratory

Argonne, II. 60439, USA

bids.

Argonne National Laburatory reserves the right to reject any and all 


\section{CONTENTS}

NOTICE TO BIDDERS .................................

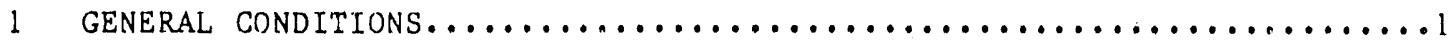

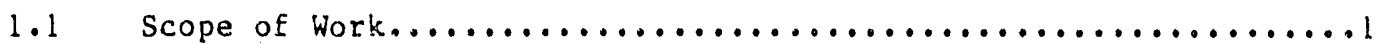

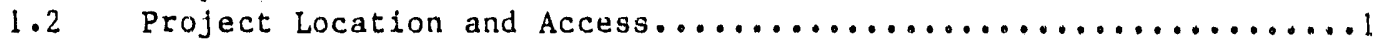

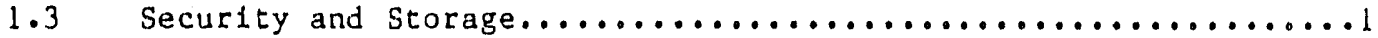

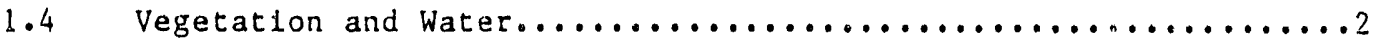

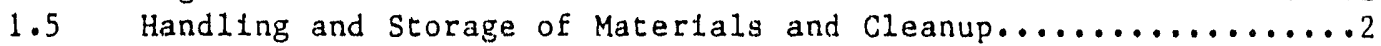

1.6 Contractor Responsibility...........................

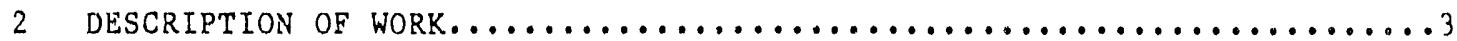

2.1 Area 1: Fertllizer and Seed.........................

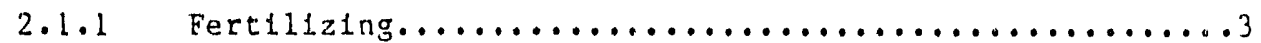

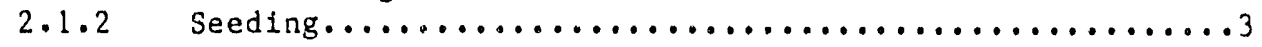

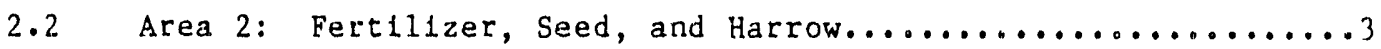

$2.2 .1 \quad$ Fertilizing.............................

2.2 .2 Seeding ..................................

2.2 .3 Harrowing..............................

2.3 Area 3: T1llage, Fertil1zer, Seedbed Preparation,

Seed, and Harrow..........................

2.3 .1 Deep T1llage............................4

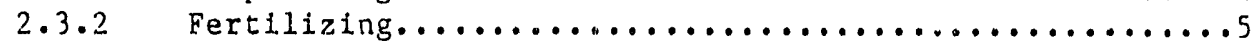

2.3 .3 Seedbed Preparation........................

2.3 .4 Seeding.................................

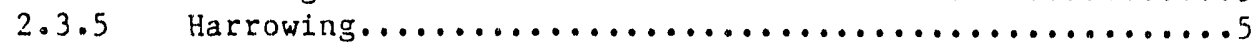

2.4 Seeding Mixture...............................

$2.4 .1 \quad$ Seed...................................

2.4 .2 Seed Mixture.............................

TABLES

$1 \quad$ Required Fertilizer and Seed......................

\section{DRAWINGS}

8C490-MTA-1 Location of Minimum Technology Applications

Project sice on the Hohenfels Training Area............9

8C490-MTA-2 Treatment Area of the Min1mum Technology

Applications Project at. Hohenfels

Training Area............................. 


$$
\square
$$


SPECLFICATIONS FOR

\begin{abstract}
MINIMUY TECHNOLOGY APPLICATIONS REHABILITATION PROJECT HOHENFEL.S TRAINING AREA, HOBRNPELS, WEST GERMANY
\end{abstract}

\title{
1 GENERAL CONDITIONS
}

\subsection{SCOPE OF WORK}

The Minimum Technology Applications Rehabilitation Project at Hohenfels Training Area, Hohenfels, West Germany, will consist of revegetating a 18.0-hectare site that is divided into four separate treatment areas of 4.5 hectares each. One treatment area w111. be fert1lized and seeded using the broadcast method. The second treatment area will be fertilized, broadcast seeded, and harrowed to cover the seed. In the third area, compacted areas (tank tralls) will be chisel-plowed to a depth of 30-40 cm, fertilized, a seedbed prepared using a disk or rototiller, broadcast seeded, and harrowed. A single application rate for fertilizer and a single seed mixture and seeding rate will be used on these three treatment areas ( 13.5 ha total). The fourth area will not be treated, but will be used in evaluating the effectiveness of the other three treated areas.

A drawing showing the relative locations, shapes, and sizes of the three treatment areas in the experiment is given on page lo of this document (drawing number 8C490-MTA-2). The amounts of fertilizer and seed required for the project are given in Table 1 on page 8 of the document.

\subsection{PROJECT LOCATION AND PROJECT ACCESS}

The Hohenfels Training Area is located about $8 \mathrm{~km}$ east of the Parsberg exit of Autobahn 3 which $1 \mathrm{~s}$ about $35 \mathrm{~km}$ northwest of Regensburg and about 51) $\mathrm{km}$ southeast of Nürnberg. Road slgns mark the route from the Parsberg exit to gate 1 of the Hohenfels Training Area.

The Minimum Technology Application Rehabilitation project site is located east of the Hohenburg road, about $0.4 \mathrm{kin}$ southeast of the abandoned village of Raversdorf, and in a wide valley of the tralning area. The location of the project site $1 \mathrm{~s}$ shown on page 9 of this document (drawing number $8 \mathrm{C} 490-\mathrm{MTA}-1)$.

Access to the site w111 be through gate 1 as shown on drawing 8C490MTA-1 unless alternate routes are arranged and clearance obtained in advance. All access to and travel on the tralning area is controlled. Clearance for entry and travel on the training area must be obtained each day from Range Control through Captain Paulson's office, Directorate of Engineering and Housing (phone number 09472-83-818).

\subsection{SECURITY AND STORAGE}

Security of all equiprent, materlals, supplies, and tools shall be solely the responsibility of the contractor. Loss by theft, vandalism, pilferage, fire, flood, or waste in no way reduces the obligation of the contractor to complete all work descrlbed herein. No payment shall be made 
for lost or damaged materlals or equipment. The contractor shall arrange to have all supplies and equipment removed from the base and stored off stte adjacent to the base each eventing. Moreover, all bulk materlals stockplled for use as part of the rehabilitation work shall be stored at a conventent location off site. Storage arrangements are to be solely the responsibility of the contractor.

\subsection{VEGETATION AND WATER}

Contractor shall avold unnecessary destruction of existing vegetation at the site unless authorized by the resident englneer for accomplishment of. work. Construction water and potable water shall be provided by the contractor.

\subsection{HANDLING AND STORAGE OP MATERIALS AND CLEANUP}

All materials shall be handled and stcred $1 \mathrm{n}$ such a manner as to preserve thelr quality and fitness for the work. The contractor shall at all times malntain the profect stte $1 \mathrm{n}$ an orderly manner and keep the site free from accumulations of debris, waste materials, or rubbish. At the completion of work, the contractor shall remove from the area all materials, tools, equiprent, and rubbish, as determined by the resident englneer.

\subsection{CONTRACTOR RESPONSIBILITY}

The contractor shall defend, protect, indemify and save Argonne National Laboratory and the United States Government, 1 ts successors and assignees, harmless against any and all clains, demands, and liability of every kind and character for any loss, damage, injury or other casualty to property whether it belongs to elther of the parties hereto or to a third person, and to persons, including the parties hereto, thelr employees and third persons, caused by, growing out of, fncldent to or resulting directly or Indirectly from the activity undertaken by the contractor assoctated with the Minimum Technology Applications Rehabilitation Project, Hohenfels Tralning Area, Hohenfels, West Germany. 


\section{DESCRIPTION OF WORK}

This description of work 18 divided into faur sections. The first three sections describe the varlous operations that are to be carried out on each of the three treatment areas. The fourth section describes the seed mixture that w1.11 be applied to the three treated areas. Area 4 W111 NOT recelve treatment.

Individual operations within each of the three treatment areas can be conducted in confunction with simflar operations on other treatment areas. However, the sequence of operations within a given treatment area are to be corried out in the order that the operations are 11 sted in this document. Any change in the sequence of the operations or modification of the operations as described here can only be made with the approval of the resident englneer.

Bldders should submit a single bid price for all necessary supplies and materials, use of equipment, implements and tools, labor and trained operators, and other assoclated costs to complete the requirements described in each section of the document.

\subsection{Area 1: Fertillzer and Seed}

Area 1 ( $4.5 \mathrm{ha}$ ) will recelve a unfform application of fertilizer by the broadcast method. Following fertilization, the seed mixture will be broadcast on the area at a unfform rate.

\subsubsection{Pertilizing}

Description. This operation shall consist of the application of dry fertllizer to the entire area using a mechanlcal broadcaster.

Requirements. The dry fertlizer shall be a free-flowing product of uniform composition, and free of consolidated materials and lumps. Fertilizer is to be applied uniformly to the entire area and of a composition to supply $25 \mathrm{~kg}$ of $\mathrm{N}, 25 \mathrm{~kg}$ of $\mathrm{P}_{2} \mathrm{O}_{5}$, and $25 \mathrm{~kg}$ of $\mathrm{K}_{2} \mathrm{O}$ per hectare.

\subsubsection{Seeding}

Description. This operation shall conslst of the application of the seed mixture to the entire area using a mechanical broadcast seeder,

Requirements. Seeding operations shall be conducted following the application of fertilizer (2.1.1). The broadcast seeder must be able to accomodate the varlous kinds of seeds in the seed mixture and uniforinly distribute the seed mixture at the rate of $75.5 \mathrm{~kg}$ pure 11 ve seed per hectare $(2.4 .2)$.

\subsection{AREA 2: FERTILIZER, SEED, AND HARROW}

Area 2 ( $4.5 \mathrm{ha}$ ) will recelve a unfform application of fertiltzer by the broadcast method. Following application of the fertilizer, the seed mixture will be broadcast on the entire area. Following application of the seed mixture, the area will be lightly harrowed to cover the seed. 


\subsubsection{Pert1lizing}

Description. This operation shall consist of the application of dry fertllizer to the entre area using a mechanlcal broadcaster.

Requirements. The dry fertilizer shall be a free-flowing product of unfform composition, and free of consolidated materials and lumps. Fertilizer is to be applied unlformly to the entire area and of a composition to supply $25 \mathrm{~kg}$ of $\mathrm{N}, 25 \mathrm{~kg}$ of $\mathrm{P}_{2} \mathrm{O}_{5}$, and $25 \mathrm{~kg}$ of $\mathrm{K}_{2} \mathrm{O}$ per hectare.

\section{2 .2 Seeding}

Description. This operation shall conslst of the application of the seed mixture to the entire area using a mechantcal broadcast seeder.

Requirements. Seeding operations shall be conducted following the application of fertllizer (2.2.1). The broadcast seeder must be able to accomodate the varlous klnds of seeds in the seed mixture and uniformly distribute the seed mixture at the rate of $75.5 \mathrm{~kg}$ pure live seed per hectare $(2.4 .2)$.

\subsubsection{Harrowing}

Description. This operatiou shall consist of lightly harrowing the entire area using an 1mplement to cover the seeds with soll.

Requirements. The harrowing operation shall be conducted following broadcast seeding $(2.2 .2)$. The harrow or other lmplement used shall lightly cover the seed with soll, but not cover the seed to a depth that will prevent. seed germination and growth.

\subsection{AREA 3: TILLAGE, FERTILIZER, SEEDBRD PREPARATION, SERD, AND HARROW}

The tank trails with compacted soll and designated by the resident engineer in drea $3(4.5 \mathrm{ha})$ will be tilled to a depth of $30-40 \mathrm{~cm}$. The entire Area 3 will recelve a unlform application of fertilizer by the broadcast method to the entire area ( 4.5 ha). Followlng ferillization, a seedbed will be prepared on those parts of the area designated by the resident engineer with less than $50 \%$ plant cover. The seed mixture will then be broadcast on the entire area ( $4.5 \mathrm{ha})$ and the entire area lightly harrowed.

\subsubsection{Deep T11lage}

Description. Th1s operation shall consist of tilling compacted areas (tank tralls) to a depth of $30-40 \mathrm{~cm}$ to loosen the soll. The resident englneer will mark the parts of the area to be deep t1lled. Th1s operation will be required on one ha or less in Area 3. Deep tillage will not be required in areas with rocks near the surface and for shallow soils.

Requirements. The deep tillage operation shall be completed prior to other operations. A chisel plow or other similar lmplement shall be used to loosen the compacted sol.1 to a depth of 30 to $40 \mathrm{~cm}$. The spacing of tines on the 1mplement shall not be more than $40 \mathrm{cin}$. Tank tralls and other areas with compacted solls as deglgnated by the restdent englneer will recelve the deep tillage operation. 


\subsubsection{Pertilizing}

Description. Th1s operation shall consist of the application of dry fertilizer to the entire area using a mechanfcal broadcaster.

Requirements. The dry fertilizer shall be a free-flowing product of untform composition, and free of consolidated materials and lumps. Fertilizer is to be applied uniformly to the entire area and of a composition to supply $25 \mathrm{~kg}$ of $\mathrm{N}, 25 \mathrm{~kg}$ of $\mathrm{F}_{2} \mathrm{O}_{5}$, and $25 \mathrm{~kg}$ of $\mathrm{K}_{2} \mathrm{O}$ per hectare.

\subsubsection{Seedbed preparation}

Descrlption. Th1s operation shall conslst of rototilling, disk harrowing, or similar operation to prepare a seedbed free of large soli clods and smooth the surface for seed application. The deep t1llage area (2.3.1), and other areas as designated by the resident engineer as having less than $50 \%$ plant cover, will recelve seedbed preparation. It is estimated that a total area of 2.5 ha or less will be treated in thls operation.

Requirements. Seedbed preparation shall be completed following the fertilizing operation (2.3.2). A rototiller, disc harrow, or stintlar implement shall be used to loosen the 5011 to a depth of 10 to $15 \mathrm{~cm}$. The deep t1llage area $(2.3 .1)$ and other areas with less than $50 \%$ plant cover as designated by the resident engineer will recelve the seedbed preparation operation.

\subsubsection{Seeding}

Description. This operation shall consist of the application of the seed mixture to the entire area using a mechantcal broadcast seeder.

Requilements. Seeding operations shall be conducted following the seedbed preparation (2.3.3). The broadcast seeder must be able to accommodate the vartous $k i n d s$ of seeds $i n$ the seed mlxture and uniformly distribute the seed mixture at the rate of $75.5 \mathrm{~kg}$ pure live seed per hectare (2.4.2).

\subsubsection{Harrowing}

Description. This operation shall consist of lightly harrowing the entire area using an implement to cover the seeds with soil.

Requirements. The harrowing operation shall be conducted following broadcast seeding $(2.3 .4)$. The harrow or other limplement used shall lightly cover the seed with soll, but not cover the seed to a depth that will prevent seed germination and growth.

\subsection{SEEDING MTXTURE}

A single seed mixture will be used on all seeded areas. Table 2.4.2 gives the plant spectes to be used, the relartve amounts of each spectes in the mixture, and the application rate per hectare. 


\section{4 .1 Seed}

Description. All welghts of seed given are for a purr 11 ve seed basis (PLS). Pure live seed for each plant species is defined as equal to the produce of percent purity times the percent germination divided by 100 .

Requirements. Information on the name and address of the seed supplier, the seed name and vartety, germination, purtty and weed seed content shall be provided to the resident englneer. Appropriate legume root inoculants will be included in the seed mixtures. (PLS).

Application of seed mixture will be on the basis of pure live seed 


\subsubsection{SEED MIXTURE}

\begin{tabular}{|c|c|c|c|}
\hline \multirow[b]{2}{*}{ Sclentiflc Name } & \multirow[b]{2}{*}{$\frac{\text { Deutscher Name }}{\text { American Name }}$} & \multicolumn{2}{|c|}{ Mixture } \\
\hline & & $\begin{array}{l}\text { Broadcast } \\
\mathrm{kg} / \mathrm{ha}\end{array}$ & $\begin{array}{l}\% \\
\text { Weight }\end{array}$ \\
\hline Ayropyron repens & $\begin{array}{l}\text { Krlechende Quecke } \\
\text { quackgrass }\end{array}$ & 7.0 & 9.0 \\
\hline Brcmus inermia & $\begin{array}{l}\text { Wehrlose Trespe } \\
\text { smooth brome }\end{array}$ & 6.0 & 8.0 \\
\hline Dastylis yzomerata & $\begin{array}{l}\text { Knaulgras } \\
\text { orchardgrass }\end{array}$ & 1.5 & 2.0 \\
\hline Festuca rubra var. rubra & $\begin{array}{l}\text { Ans laufertr. Rotgchilngel } \\
\text { red fescue }\end{array}$ & 1.5 & 2.0 \\
\hline Phataris arundinacea & $\begin{array}{l}\text { Rohrglanzgras } \\
\text { reed canarygrass }\end{array}$ & 1.5 & 2.0 \\
\hline Lotus somiculatus & $\begin{array}{l}\text { Hornschotenklee } \\
\text { birdsfoot trefoll }\end{array}$ & 5.0 & 7.0 \\
\hline Irifolium repens & $\begin{array}{l}\text { Welssklee } \\
\text { wh1te clover }\end{array}$ & 3.0 & 4.0 \\
\hline Soale cereale & $\begin{array}{l}\text { Roggen } \\
\text { rye }\end{array}$ & 50.0 & 66.0 \\
\hline TOTAL & & 75.5 & 100.0 \\
\hline
\end{tabular}


TABLE I Required Fartllizer and geed

\begin{tabular}{|c|c|c|}
\hline Matertal & $\begin{array}{l}\text { Undt of } \\
\text { Meature }\end{array}$ & $\begin{array}{l}\text { Total } \\
\text { Requedred }\end{array}$ \\
\hline \multicolumn{3}{|l|}{ Fertlitzer } \\
\hline N nutitent & $\mathrm{kg}$ & 338 \\
\hline $\mathrm{P}_{2} \mathrm{O}_{5}$ nutrient & $\mathrm{kg}$ & 338 \\
\hline $\mathrm{K}_{2} \mathrm{O}$ nutrient & $\mathrm{kg}$ & 338 \\
\hline \multicolumn{3}{|l|}{ Seed (Pura Llve Seed) } \\
\hline Ayropyron rapanes & $\mathrm{kg}$ & 94.50 \\
\hline Bromus inermirs & $\mathrm{kg}$ & 81.00 \\
\hline Daotiglia jlomerata & $\mathrm{kg}$ & 20.25 \\
\hline Fastuad rubra & $\mathrm{kg}$ & 20.25 \\
\hline Phalaria arundinasea & $\mathrm{kg}$ & 20.25 \\
\hline Lotus oornioulatus & $\mathrm{kg}$ & 67.50 \\
\hline Trifolitum repens & $\mathrm{kg}$ & 40.50 \\
\hline Soale cerreale & $\mathrm{kg}$ & 675.0 \\
\hline
\end{tabular}




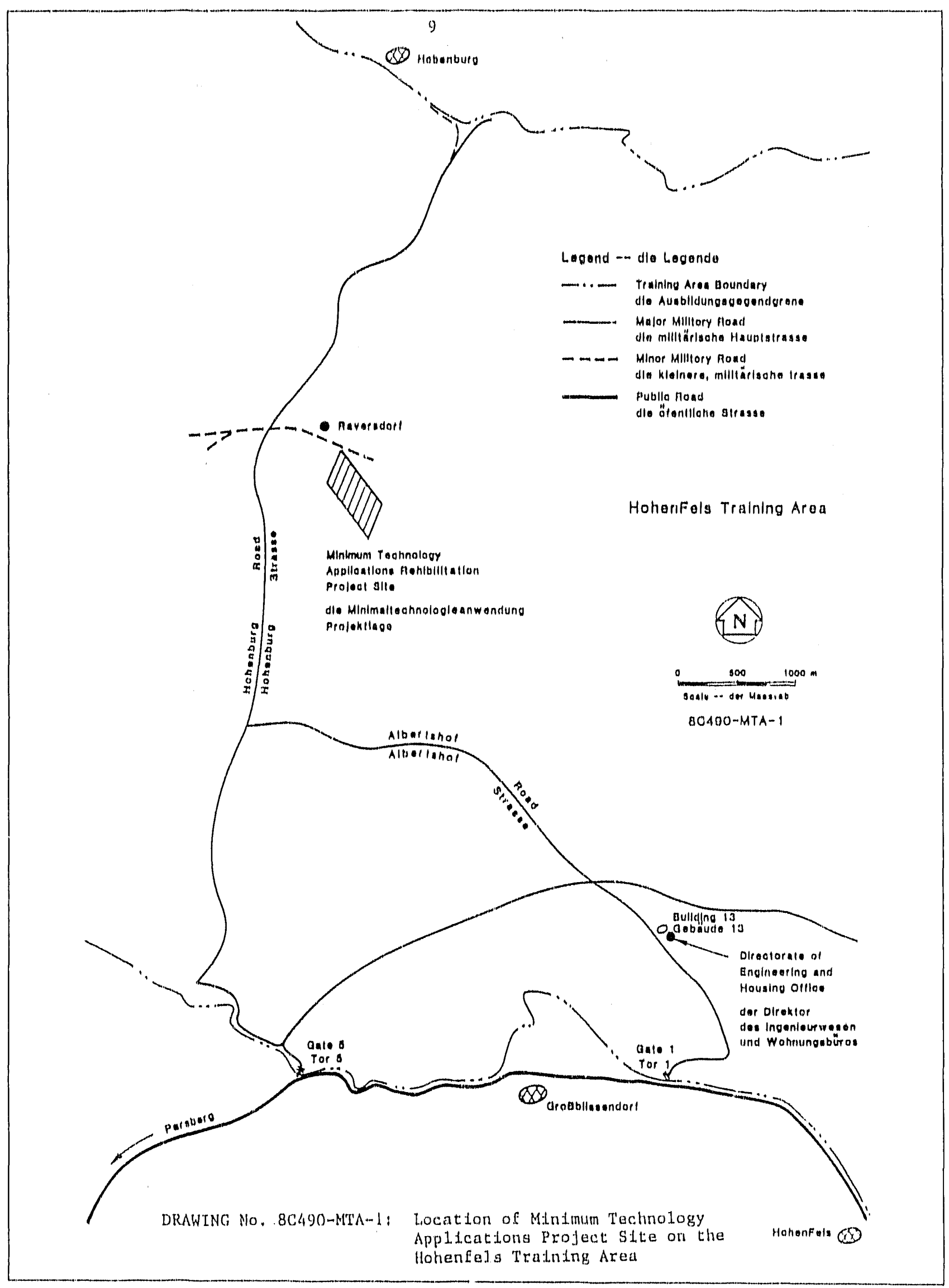




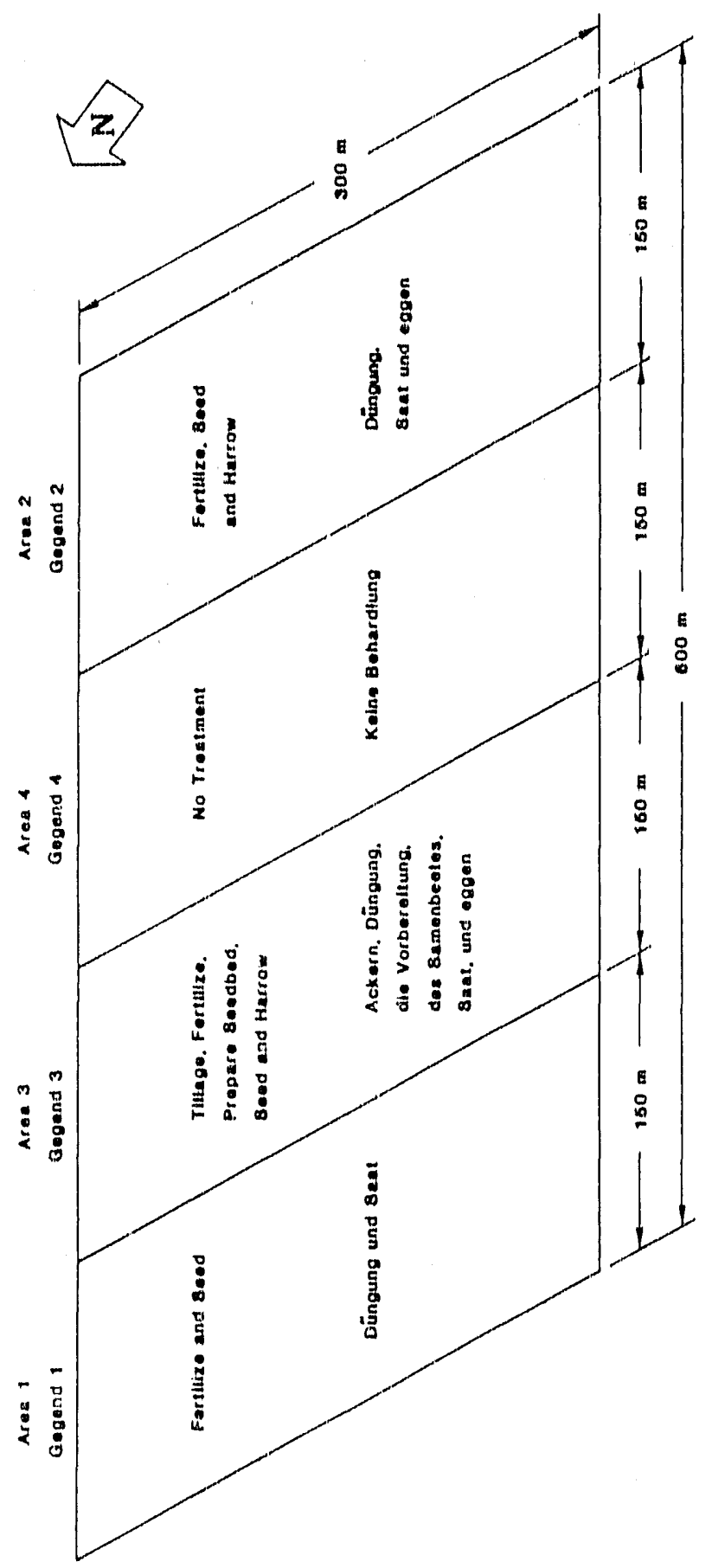

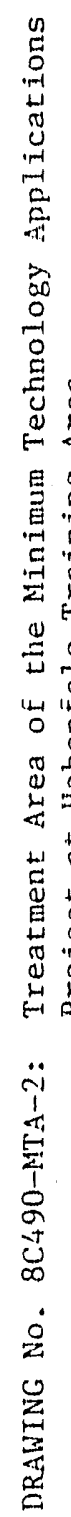


Appendix B:

Bid Package for Minimal Technologies Application Rehabilitation Project 


\section{BID PACKAGE}

POR

MINIMUM TECHNOLOGY APPLICATIONS REHABILITATION PROJECT HOHENFELS TRAINING AREA, HOHENFELS, WEST GERMANY

$$
\text { subintted by }
$$

COMPANY NAME

ADDRESS

TELEPHONE

PERSON IN CHARGE OF THIS PROJECT:

NAME

TELEPHONE

by

Renewable Resources Section

Energy and Environmental Systems Division Argonne National Laboratory

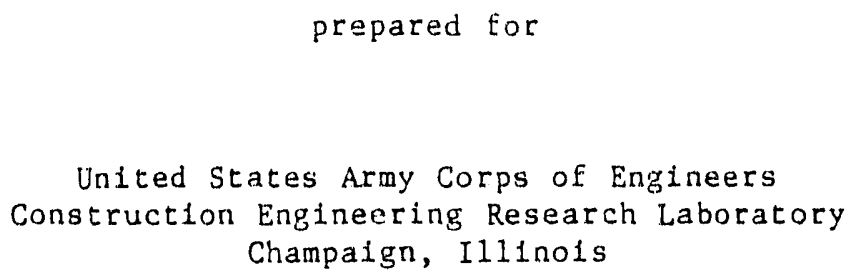

May 1987 


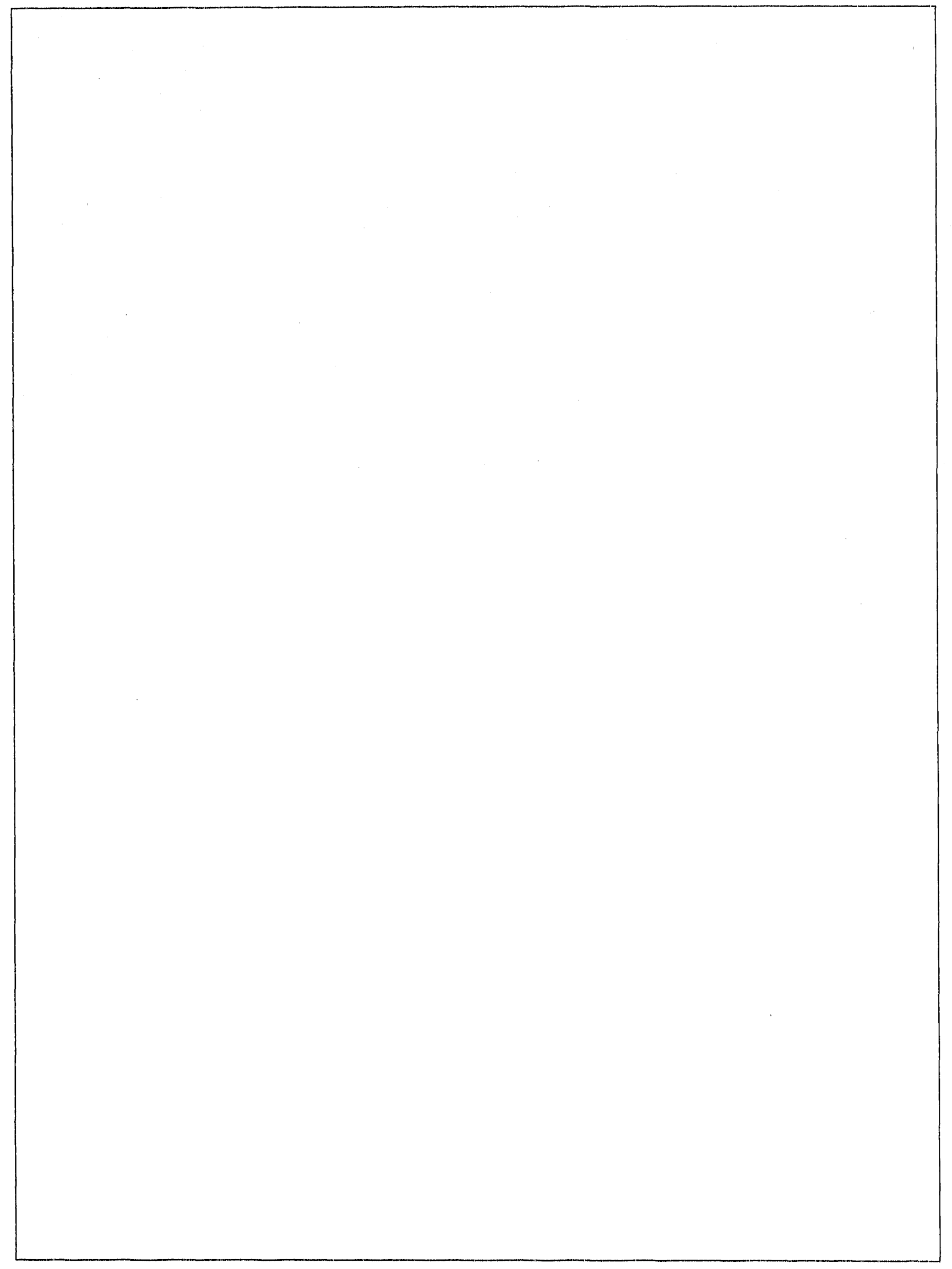


METHOD FOR THE EVALUATION OF CONTRACTORS

A point assignment system has been developed and the bidder with the highest total point count will be awarded the contract. Points will be assigned as follows:

A. Bid price: one (1) polnt for each one (1) percent difference from the average bid price.

([average bid - bid price]/average bid) $\times 100=$ points.

\section{B. Schedule:}

Starting date: Subtract one-half point (0.5) for each working day after 8 June 1987, (suggested starting date) no points given for starting before 8 June 1987 .

Duration of work: Subtract one-tenth point (0.1) for each working day more than 4 working days to complete the project. No points awarded for estimate of 4 working days or less.

\section{Equipment, personnel, and work history:}

Any bidder who does not have the equipment and personnel necessary to satisfactorily complete the rehabilitation effort, in the judgment of the Argonne representative, w111 be rejected. However, points w111 be awarded to bidder with above-average equipment, personnal, and contractor history. Information on work history will be developed from telephone interview with persons representing organlzations having related work done in the past.

\section{Average contractor record - no points awarded.}

1. Has most of the equiprent and personnel necessary and avallable to complete the rehabilitation eftort on schedule.

2. Usually completes jobs on schedule.

3. Done acceptable quality work.

4. Has done one (1) or more fob related to rehabilitation effort.

\section{Good contractor record - half $(0.5)$ polnt awarded.}

1. Has all equipment and personnel necessary and avallable to complete the rehabilitation effort on schedule.

2. Completed jobs on schedule. 
3. Done above average qualdty work.

4. Has done several (3-5) Jobs related to rehabllitation effort.

\section{Excellent contractor record - oue (1) point awarded.}

1. Has all equipment and personnel necessary and avallable to complete the rehabllitation effort on schedule.

2. Has a record of completing job on or ahead of schedule.

3. Done exceptional quality of work.

4. Has done many (more than 5) jobs related to rehabilitation.

Because of the several factors and combinations considered in the area of equipment, personnel, and work history, fractional parts of a polnt may be awarded. However, no more than one (1) total point can be awarded in this area. 
TABLE 1 Bid Sheet for Minimum Technology Applications Rehabilitation Project, Hohenfels Training Area, Hohenfels, West Germany

COMPANY NAME

TELEPHONE

\begin{tabular}{|c|c|c|c|c|c|}
\hline Section No. & Description & Quantity & $\begin{array}{l}\text { Unit of } \\
\text { Measure }\end{array}$ & $\begin{array}{l}\text { Unit } \\
\operatorname{Cost}\end{array}$ & $\begin{array}{l}\text { Total } \\
\text { Cost }\end{array}$ \\
\hline 2.1 & Fertillze and seed & 4.5 & ha & & \\
\hline $2 \cdot 2$ & Fertllize, seed and harrow & $4 \cdot 5$ & ha & & \\
\hline $2 \cdot 3$ & $\begin{array}{l}\text { T111, fertilize, prepare } \\
\text { seedbed, seed, and harrow }\end{array}$ & 4.5 & ha & & \\
\hline 2.4 & Seeding mixture & $1019.25^{*}$ & $\mathrm{~kg}$ & & \\
\hline
\end{tabular}

* Pure Live seed 


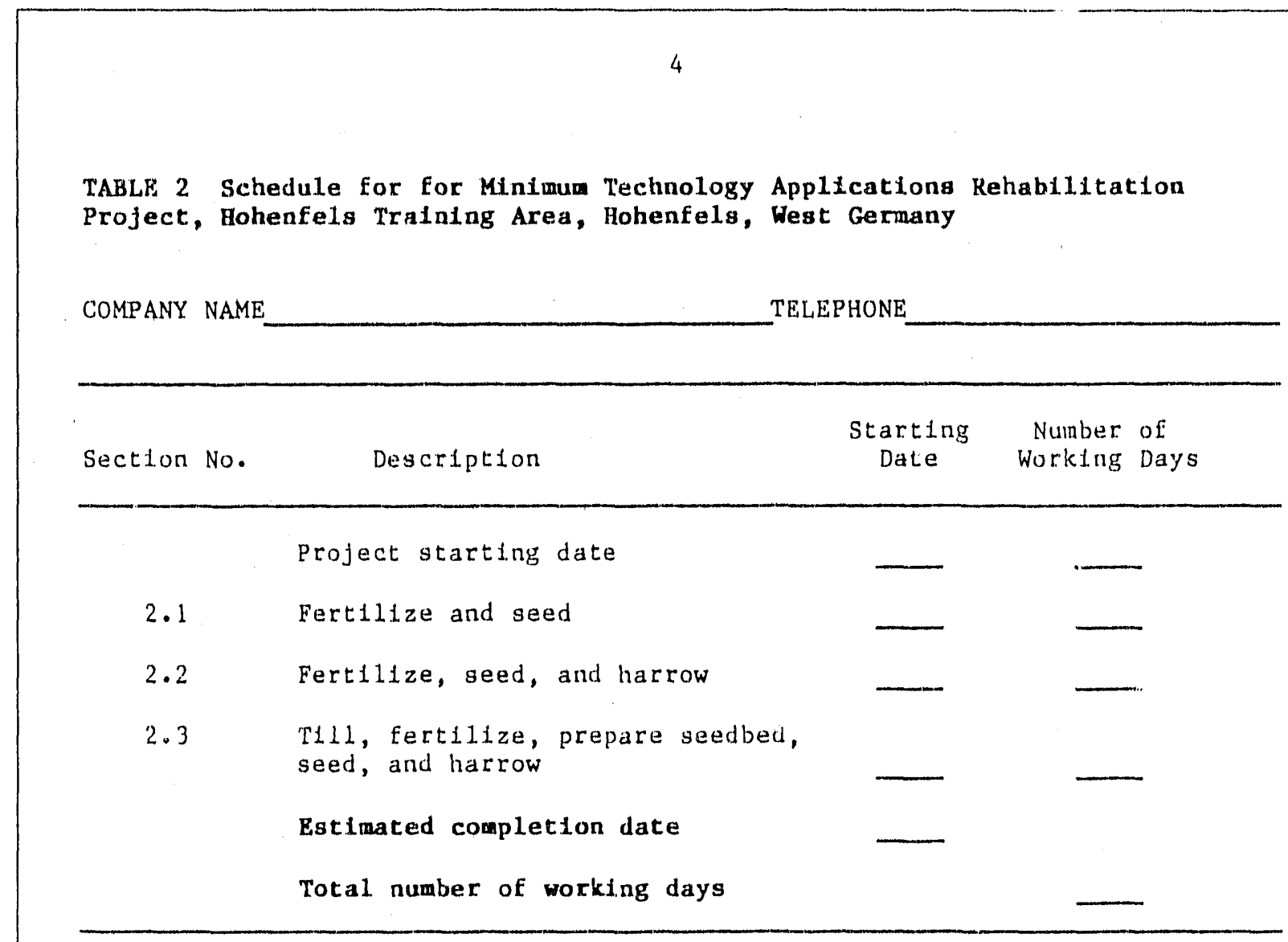


5

EQUIPMENT

COMPANY NAME:

TELEPHONE

Major equipment and Implements to be used on this profect:

Description

Type (stze, etc.)

Number 
6

PERSONNEL

COMPANY NAME :

TELEPHONE

Job category and number of Individuals to be employed on this project:

Job Category

Number 
WORK HIS'TORY

COMPANY NAME:

TELEPHONE

Work history ralated to rehabllitation efforts:

Location or Name of Project:

S1ze (ha)

Type of work (grading, seedling, hydromulch, etc.)

Name of Individual to contact

Telephone number:

Location or Name of project:

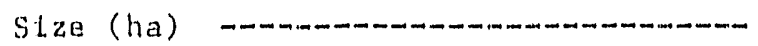

T'ype of work (gradting, seading, hydronulch, atc.)

Name of Individual to contact:

Telephone number:

DUPLICATE THIS PAGE IF FOR MOKF THIAN TWO (2) RULA'TED JOBS. 

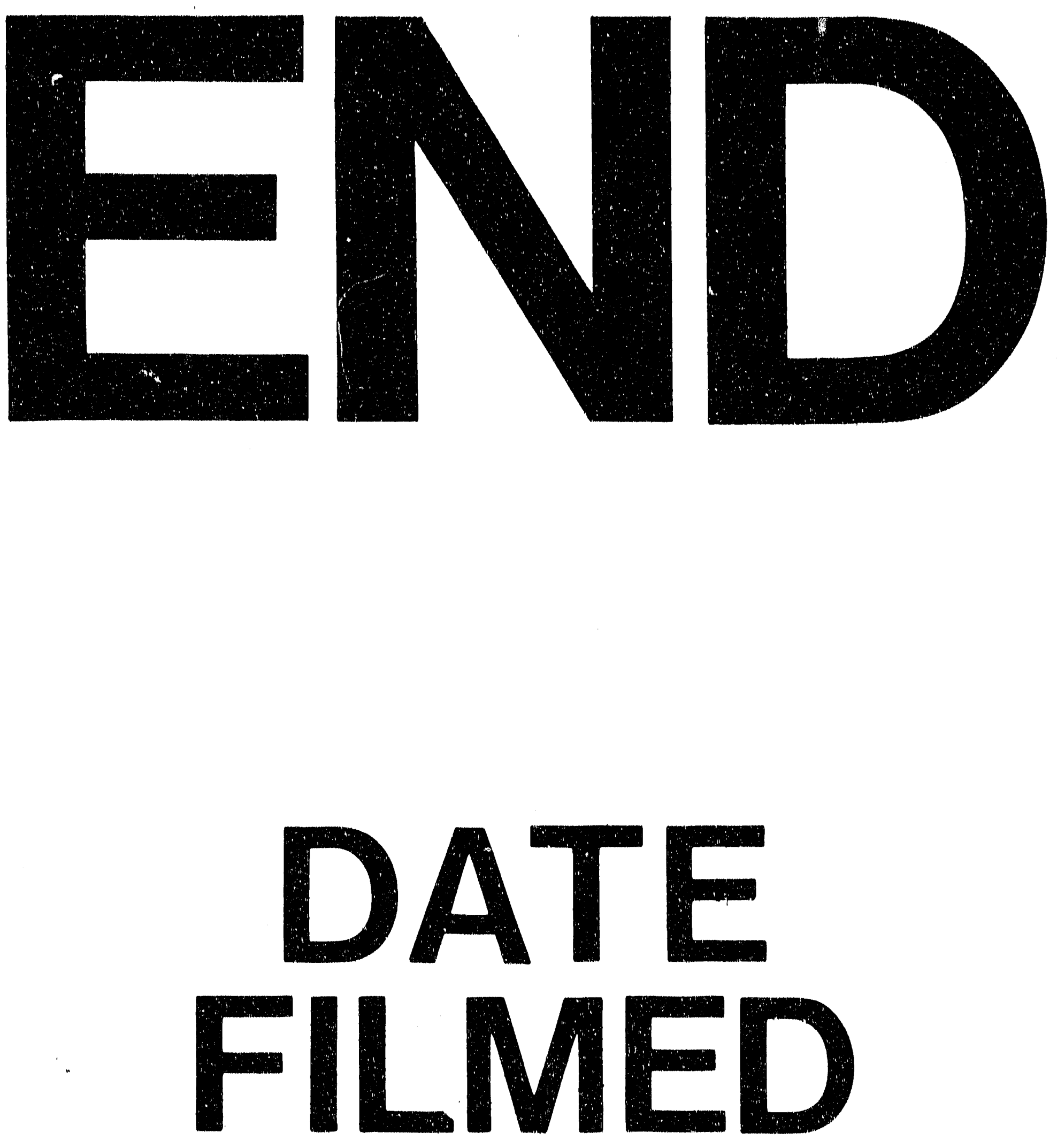

1

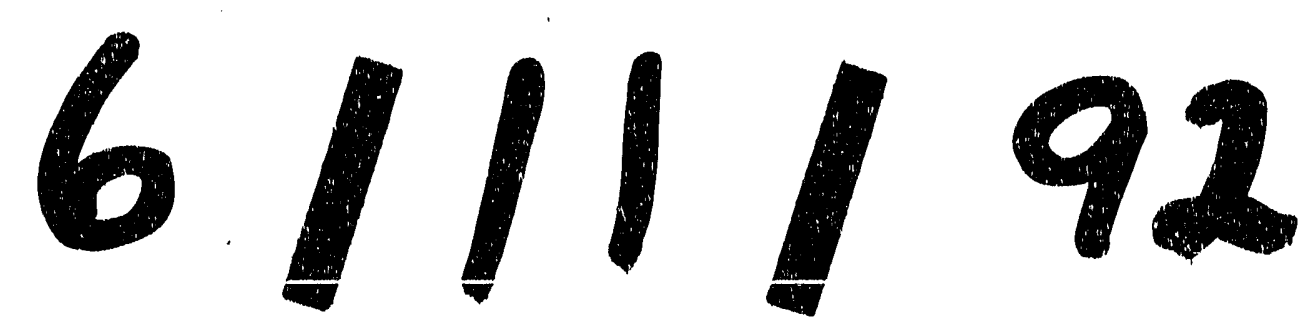




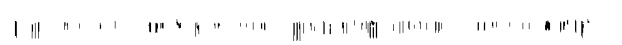

